\title{
ANALYSIS OF THE MUSTANG MOVIE THE BASIS OF GENDER ROLES IN SOCIETY AND REPRESENTATION OF THE WOMAN IN TURKISH CINEMA
}

\author{
Fevzi KASAP \\ Near East University, KKTC \\ fevzi.kasap@neu.edu.tr \\ https://orcid.org/0000-0003-3965-3837 \\ Ayhan DOLUNAY \\ Near East University, KKTC \\ ayhan.dolunay@,neu.edu.tr \\ https://orcid.org/0000-0003-1862-4500 \\ Ali SOLMAN \\ alisolman@hotmail.com \\ https://orcid.org/0000-0002-6225-8467
}

\begin{abstract}
There is high pressure of gender mainstreaming created by society, which everyone is affected by. A person may feel that they need to fit the typical roles given by society, in order to be accepted and to avoid being alienated. Society lives by a patriarchal structure. In other words, the world is mostly male dominant. Women's views are less meaningful then males, which often means that women are discriminated and less valued. Patriarchal structure also affects the gender roles. Gender roles are learnt from a young age and people are encouraged to abide to their role. These roles are demonstrated by family, school and media. Mass communication plays a huge role on creating and re-creating these gender roles. This article will look further into how media plays a significant role in gender roles. In Turkish cinema; it is often seen that women will always play a supporting role to the male and rarely play independent lead characters. This article will be looking at a recent Turkish film 'Mustang' (2015), as it validates the idea of gender roles and the significance of women's roles in movies.
\end{abstract}

Keywords: Gender Roles in Society, Woman, Turkish Cinema, Mustang Movie.

\section{TOPLUMSAL CINSIYET ROLLERİ VE TÜRK SINEMASINDA KADININ SUNUMU TEMELINDE MUSTANG FILM İNCELEMESI}

\section{ÖZ}

Toplumsal cinsiyet rollerinin toplumdaki bireyler üzerindeki etkisi yadırganamaz. Toplumsal cinsiyet rollerini toplumun kendisi üretir. İçerisinde yaşayan her bireye de, bu kurallara uyması için yaptırımlarda bulunur. Birey bu rolleri hayatının her aşamasında sergilemek zorundadır. Sergilemediği sürece, toplum tarafından kabul edilmez, dışlanır. Toplumlar ataerkil bir düzene, yani erkeklerin egemen olduğu bir düzene sahiptir. Bu düzen ile kadınlar, erkeklerden daha az söz hakkına sahip olmuş, ikinci planda kalmıştır. Toplumsal cinsiyet rolleri de, bu ayrımın derinleşmesinde oldukça etkilidir. Toplumsal cinsiyet rolleri toplumda yer alan pek çok kurum tarafından, bireye doğduğu ilk günden itibaren öğretilmektedir. $\mathrm{Bu}$ kurumlara örnek olarak aile, okul ve bu makalenin asıl odaklanacağı kitle iletişim araçları verilebilir. Kitle iletişim araçları, toplumsal cinsiyet rollerinin üretilmesine ve devam ettirilmesine katkıda bulunmaktadır. Ataerkil toplum düzeninden dolayı kadınların ikinci planda oluşu, kitle iletişim araçlarına; özellikle sinemaya da yansımaktadır. Türk 
sinemasında kadının sunumu incelendiğinde; kadın filmin ön planında yer alamamakta, sadece olayların başlatıcısı rolünü üstlenip geri planda var olmaktadır. Hem yakın dönem Türk sineması örneği olduğu, hem toplumsal cinsiyet rolü kavramını etkili bir şekilde işlediği hem de kadının filmdeki önemini yükselttiği için, çalışmada, 2015 yılı yapımı "Mustang" filminin içerik çözümlemesi yapılmaktadır.

Anahtar Kelimeler: Toplumsal Cinsiyet Rolleri, Kadın, Türk Sineması, Mustang Filmi.

\section{GİRIŞ}

Toplumsal cinsiyet rolleri, bireyler henüz doğmadan onların hayatlarını etkilemeye başlar. Bu roller, birey olgunlaştıkça daha da ağırlaşır, daha da artar. Toplumsal cinsiyet rolleri, üzerimize giydiğimiz giysiler gibidir. Erkek çocuk doğmadan önce nasıl ki kıyafetleri mavi renk olarak seçiliyorsa; erkeğe toplum tarafından da mavi kıyafeti uygun görülür. Mavi burada erilliği, "adam gibi adam" olmayı ve toplumun erkekten beklediği her şeyi simgeler. Kadın ise pembe kıyafeti giyer. Ne erkek, ne de kadın ömrünün sonuna kadar bu kıyafeti çıkaramaz, rengini değiştiremez. Bu toplumsal cinsiyet rolü kıyafeti, bireyi; toplumsal yaşamı içerisindeki her yerde etkiler. Gerek kamusal alanda, gerek özel alanda, gittiği ve bulunduğu her yerde, giydiği bu kıyafetin gerektirdiği gibi davranışta bulunması beklenir.

Toplum, cinsiyet rollerini kendisi oluşturur. Bu roller doğal değildir, üretilir. Toplum, birey doğduktan sonra, içindeki kurumlar yoluyla yeni doğmuş bireylere beklentilerini aktarır. Toplumun bu beklentileri katıdır, uyulması zorunludur, sorgulanamaz. Birey toplumsallaştıkça, bu kuralları öğrenmeye ve pekiştirmeye başlar. Toplumdaki bireyler de karşılıklı olarak birbirini etkiler. Birbirleriyle öğrendikleri rolleri paylaşarak, o rollerin pekişmesini sağlarlar. Erkekler, kadınlardan önemli olduklarını, bir ailede yegane söz sahibinin erkeğe ait olduğunu öğrenir. Cinsiyetinin kaba olma, kavgacı olma, kadınlara ilgi duyma, güçlü olma gibi rolleri gerektirdiğini öğrenir. Diğer taraftansa kadınlar; erkeklerden daha değersiz olduğunu, erkeklere itaat etmesi gerektiğini ve en önemlisi namuslu olması gerektiğini öğrenir. Kadın narin olmalıdır; söz dinlemeli, başına buyruk olmamalıdır. Erkeklere, toplum tarafından cinsellik yasaklanmamışır. Hatta toplum tarafından ilişkiye girmeleri için cesaret de verilmektedir. Diğer yandansa kadın cinselliği kati kurallarla yasaklanmıştır. Kadın; evleneceği güne kadar "namusunu korumalı"dır.

Günümüze geldiğimizdeyse pek çok toplumsal cinsiyet rolünün değiştiğini, bazılarının ise aynı kaldığını görmekteyiz. Toplumlar durağan değildir, sürekli değişir. Cinsiyet rolleri de toplum tarafından üretildiği için, roller de değişir ve gelişir. Örneğin kadınlardan beklenen namus kavramı yıllar içinde değişmiştir. Eskiden kadının evden çıkmak istemesi bile namussuzluk sayılırken, artık kadın daha özgürdür. Eskiden bir kadının işte çalışmak istemesi ayıplanmaktaydı. Günümüzde toplum değiştiği için kadınların çalışmasına normal gözüyle bakılmaktadır. Bu değişikliklere rağmen, toplumda değişmeyen bir şey varsa, o da ataerkil düzendir. Ataerkil düzenin, toplumsal cinsiyet rolleri üzerindeki etkisi büyüktür. Erkek ile kadın arasındaki eşitsizliklerin yaratılmasını ve devam ettirilmesini sağlar. Bu eşitsizlikler de rolleri etkilemektedir.

Toplumsal cinsiyet kavramı, özellikle XX. YY'ın ortalarından sonra, kitle iletişim araçları vasıtasıyla da aktarılmaya başlandı. Kitle iletişim araçlarında verilen iletiler, bireyleri etkilemekte, onların davranışlarını şekillendirmektedir. Davranışları şekillendirirken, onların devam ettirilmesini de sağlamaktadır. Bireyler gördüklerinden etkilenmekte, ona göre davranmak istemektedir.

Sinema da kitle iletişim araçlarından biridir. Günümüzde, eskisi kadar yaygın olmasa da, toplumsal cinsiyet rollerinin üretilmesi ve bunları bireylere pekiştirmesi yönünden etkili bir iletişim aracıdır. Yönetmenler film yaparken, bilinçli ya da bilinçsiz bir şekilde bu rolleri seyircisine aktarır. Özellikle klasik anlatı sinemasında bu rollerin pekiştirilmesi daha kolaydır. Klasik anlatı sinemasında filmlerin 
asıl amacı; seyirciyle kahramanın özdeşleşmesi olduğu için bu çok kolay bir şekilde gerçekleşir. Seyirci gördüklerini sorgulamaz, özdeşleşir ve olduğu gibi kabul eder.

Türk sineması da toplumsal cinsiyet rollerinin pekiştirilmesi açısından önemlidir. Türk filmlerinde, Türk toplumsal yaşantısının ve rollerinin yansımaları görünür. Ataerkil düzen egemendir ve bu; Türk sinemasının her filminde gözlemlenebilmektedir. Türk filmlerinde kadınların ön planda olamadığı, ana karakter olamadığı, sadece olayları başlatıcı bir işlevinin bulunduğu görülmektedir. Olayları başlatıp, çevre hikayeler içinde yer alır. Erkek ise kadının başlattığı olayların ana karakteri olur. Türk sineması yıllara göre ayrıldığında, 1980'lerden itibaren kadının filmlerde daha çok yer almaya başladığı görülür. Ancak sadece olayların başlatıcısı rolünde kalmakta, daha derine inememektedir.

\section{LITERATÜR TARAMASI}

Bu makalede incelenecek 2015 yapımı "Mustang" filmi, toplumsal cinsiyet rollerinin eleştirilmesi bakımından önem arz etmektedir. Film ile ilgili diğer bir önemli unsur da; Türk sinemasının, diğer filmlerindeki kadın karakterlere göre, bu filmdeki kadın karakterlerin filmin ön planında yer almaları; konunun, onların çevresinde şekillenmesidir.

Kadın karakterlerin, diğer filmlere göre bu filmde daha önemli bir yerde olması 1şı̆̆ında; toplumsal cinsiyet rollerinin, bu filmdeki karakterler üzerinde nasıl bir etkisinin olduğu, bu makalenin problemini oluşturmaktadır. Bu kapsamda, çalışmada, Mustang filmindeki toplumsal cinsiyet rollerinin ve bu rollerin karakterleri nasıl etkilediğinin incelenmektedir.

Çalışmanın sınırları, temelde Mustang filmi olmak üzere, Türk sinemasındaki toplumsal cinsiyet rollerinin ve kadının sinemadaki rolünün örneklerini incelemek açısından ele alınan, "Gelin", "Acı Hayat”, “Aşk Filmlerinin Unutulmaz Yönetmeni”, "İtiraf”, "Kış Uykusu” filmleri ile çizilmektedir

Çalışma, bir durum saptama makalesidir. Çalışmada, içerik analizi yöntemi kullanılmaktadır. İçerik çözümleme yöntemi; insanın davranışlarının gözlemlenmesiyle değil, kişilerin ortaya koyduğu sembolik davranışlarının ya da iletişim materyallerinin (bu çalışma için Mustang filminin içeriğinin) çözümlenmesiyle gerçekleştirilmiştir.

Toplumsal cinsiyet rollerinin, sinema filmlerinde yansımalarının bulunduğu inkar edilememekte; bu roller filmin içeriğini ve filmdeki karakterleri de etkilemektedir. Bu nedenle, toplumsal cinsiyet rollerinin "Mustang" filmindeki karakterler üzerinde nasıl bir etkisinin bulunduğu içerik çözümlemesiyle elde edilecektir.

Toplumsal cinsiyet rollerinin, sinema filmlerindeki karakterleri etkilediği sonucuyla yola çıkıldığında, araştırmanın evrenini; Türk sinemasının başladığı yıl olan 1914 ile 2016 arasında çekilmiş Türk filmleri oluşturmaktadır. 102 yıllık geçmişi olan Türk sinemasındaki her filmin içerik çözümlemesi yapılamayacağı için, evrenin içindeki bir örneklem seçilmiş̧ir. Yakın dönemde gösterilmiş "Mustang" filmi, bu araştırmanın örneklemidir.

Örneklem ile ilgili içerik çözümlemesi yapılırken şu noktalar üzerinde durulmuştur: Karakterlerden beklenen toplumsal cinsiyet rolleri, ailenin, karakterler üzerindeki yaptırımları, komşuların ve kamu bireylerinin karakterler üzerindeki yaptırımları, otorite, toplumsal cinsiyet rollerine uyulmaması durumundaki yaptırımlar, karakterlerin, toplumun isteklerine karşı gösterdiği davranışlar.

\section{TOPLUMSAL CINSIYYET KURAMI}

Haralambos (1984) (2003 yılında aktaran: Uğurlu); doğada yaşayan her canlının biyolojik olarak üreme işlevi bakımından ikiye ayrıldığını; bu ayrılığın sosyologlar, antropologlar, biyologlar tarafından da kabul edildiğini söylemektedir. Bu biyolojik cinsiyet ayrımından doğan kadın ve erkek kavramlarını da; içine doğulan toplum oluşturmaktadır. 
Bu iki ayrı kavramdan beklenen kimlik ve karakteristik davranışlar da farklı olmaktadır. Biyolojik cinsellik olgusu, içine doğulan toplumun, toplumsal ve kültürel yapısı ile şekillenmekte, buna toplumsal cinsellik olgusu da eşlik etmektedir (Uğurlu, 2003). Örneğin; kadından, doğduğu günden itibaren ev işleri yapması, yemek yapmayı öğrenmesi, namuslu olması, iyi bir anne olması, eşini mutlu etmesi vb. beklenir. Aynı şekilde; erkekten de güçlü olması, baskın olması, evini ve ailesini geçindirecek parayı kazanması vb. beklenir.

Toplumsal cinsiyet, içine doğulan toplum tarafından kazanılır (Illich, 1996). Toplumsal cinsiyet rolleri doğumla birlikte öğrenilmeye başlanır ve bireyin hayatının sonuna kadar da devam eder. Toplumsal cinsiyet rolleri bireye nasıl davranması gerektiğini öğretir, toplumun beklentilerini aktarır.

Birey; cinsiyetinin gerektirdiği toplumsal cinsiyet rollerini ve bu rollerin davranış biçimlerini önce ailede öğrenmeye başlar. Aile içinde anne ve babanın, kız ve erkek çocuklarına olan davranışları farklı olmakta, çocuk doğduğu ilk andan itibaren bu farklı davranışlarla, farklı cinsiyet rollerini benimsemektedir (Suğur, 2006). Zamanla büyüyen çocuk okula gitmeye başlar; Althusser'in (2015) bahsettiği devletin ideolojik aygitlarıyla (okul da ideolojik aygitlardan biridir) cinsiyetinin gerektirdiği uygun davranış şekillerini daha yoğun bir şekilde öğrenmeye devam eder. Okulda çocuk hem devletin ideolojisini hem de toplumsal cinsiyet rollerini öğrenir. XX. YY. itibariyle kitle iletişim araçları; özellikle televizyon, toplumun bir sonraki bireylere aktarmak istediği toplumsal cinsiyet rollerinin en etkin bir şekilde aktarıldığı yer olmuştur.

Toplumsal cinsiyet; kültüre benzetilebilir. Nasıl ki kültür; insanların oluşturduğu, doğal olarak var olmayan bir olguysa; toplumsal cinsiyet kavramını da, bir kültüre ait insanlar üretir. Toplumdaki bireylerin etkileşimiyle, bir bireyden diğerine; bir nesilden diğerine aktarılarak tekrar ve tekrar üretilmektedir. Toplumsal cinsiyet kavramının bireyden ayrı düşünülmesi mümkün değildir (Lorber, 1994; aktaran: Erdal, 2010. s.5). Eğer bir toplumsal cinsiyet olgusundan bahsediliyor ise; ayn1 zamanda o toplumu oluşturan bireylerden de bahsediliyor demektir. Bu kavram ya da olgu; bireylerin gösterdiği davranış kalıplarının genellenmesi ile oluşturulmaktadır. Bilim insanlarınca kadın ya da erkek olarak doğmak biyolojik bir gerçeklik olarak kabul görmektedir. Ancak; kişi, kadın ya da erkek olmayı, doğduğu andan itibaren başlayan ve ölümüne kadar süren toplumsallaşma süreci içerisinde öğrenmektedir (Uğurlu, 2003).

Toplumsal cinsiyet kavramı, biyolojik olarak insanın sahip olduğu cinsiyetten farklıdır. Bu farklılı̆̆ın, kavramsal olarak ilk kez ortaya atılması 1986 yılında, Robert Stoller tarafından gerçeklemiştir (Erdal, 2010). "Gender" yani toplumsal cinsiyet sözcüğü, sosyolojiye ilk kez Ann Oakley tarafindan getirilmiştir. Ann Oakley; sex(cinsiyet) kelimesinin biyolojik olarak kadın ve erkek ayrımını anlattığını, gender(toplumsal cinsiyet) kelimesinin de; erillik ve dişillik arasındaki toplumsal farklılığ anlattığını söyler (Gordon, 2003).

Connel (2016), toplumsal cinsiyeti açıklarken; önce çalışılan sonra da sahnelenen bir tiyatro metni örneğini verir. Bu metinde; toplumdaki bireylerden beklenen roller yer almaktadır. Bu metnin senaristi toplumun kendisidir. Birey, doğduğu andan itibaren metinde yazan rolleri çalışmak, benimsemek ve sahnelemek zorundadır. Kadınlar ve erkekler için farklı roller belirlenmiş̧ir. Bu rollerin içinde giyim kuşam kodları, davranış kodları, normlar ve yasaklar, namus gibi kodlar bulunmaktadır. Birey, sergilenilmesi istenen rolleri sergilerken, çevresindeki bireylerle de etkileşimde bulunur. Bu etkileşim sırasında hem kendi toplumsal cinsiyet rolleri şekillenir hem de diğer bireylerin rollerini de etkilemeye başlar. $\mathrm{Bu}$ etkileşme devam ettikçe de; toplumsal cinsiyet rollerinin devamlı olarak üretilmesi sağlanmış olur.

Toplum bir bireye; farklı zaman ve durumlarda farklı şekillerde davranması için farklı toplumsal rol davranışları öğretmektedir. Örneğin; kadın, kimi zaman iş kadınıdır, kimi zaman annedir. Her değişik durum için kadın farklı rollerde davranışlar sergilemelidir. Aynı şekilde erkek de; baba, iş adamı veya koca rollerine sahiptir ve her biri için farklı davranışlar sergilemelidir (Ataman, 2002). Eğer birey, bu 
rolleri sergilemekte sorunlar yaşarsa; o zaman kişi, nasıl davranması gerektiğiyle ilgili uyarılar alır ve bu uyarılara uyarak, kendisini düzelterek, o şekilde davranması beklenir (Vassaf, 2016).

Toplumsal cinsiyet rolleri kültür gibidir. Toplumdaki değişikliklere bağlı olarak değişmekte, yeniden oluşturulmaktadır. Toplumda yaşanılan değişim sonrası, bireyin yeni duruma uygun toplumsal cinsiyet rolleriyle hareket etmesi ve yeni duruma uygun düşüncelere sahip olması beklenir (Ataman, 2002).

Toplumda yer alan kadın ve erkeklerle ilgili oluşturulan değerlerin, onların rollerini de belirleyip etkileyerek, bireysel söyleme taşıdıklarını belirten Ataman (2002), bu bireysel söylem yoluyla bireylerin kafasında erkek ya da kadınların davranışları için katı stereotipler de oluştuğunu ifade etmektedir. Erkek ve kadınların oluşturduğu "erkek böyle davranır, kadın şudur" stereotipleri, toplumun değişmesiyle de değişmekte, yeni stereotiplerin oluşmasını sağlamaktadır. Örnek verilecek olunursa; Türk toplumunda eskiden kadınların çalışması toplum tarafından kabul edilmemekteydi. Kadın evinde oturmalı, yemek yapmalı, ev işleriyle uğraşıp çocuklarına "annelik" yapmalıydı. Bu durumlara uygun düşüncelere sahip olmalı, toplumun isteklerini gerçekleştirmeliydi. XX. YY'ın ortalarından sonra ise; toplumda yaşanan değişmeler ile kadınlar iş hayatına adım atmaya başlamış ve "kadın" stereotipi değişmeye başlamış, bununla beraber de yeni roller, değerler oluşturulmaya başlanmıştır.

Günümüzdeki toplumların ataerkil düzenle oluşturulduğu görülür. Bu düzen; kadın ve erkek arasında eşit olmayan toplumsal ilişkiler ve cinsiyet rolleri oluşturmaktadır. Deborrah Tanner (2013) sosyal dilbilim üzerine yaptığı çalışmalar sonucu; erkeklerin toplumsal kuralları oluşturduğunu, kadınların ise bu oluşturma sürecinden uzak kaldığını belirtir. Ataerkil toplum olduğu için; erkeklerin davranışları "normal", kadınların davranışları ise "normal olmayan" ya da "farklı" olarak kabul edilmektedir.

Ataerkil düzenin ve toplumsal cinsiyet rollerinin kadınlar ve erkekler arasında eşit olmayan güç ilişkilerini oluşturduğu düşüncesiyle ilgili Illich (1996) insanda bulunan sağ ve sol el örneğini vermektedir. Bu örneği verirken de; kadının sol el ile temsil edildiğini söyler. Sol elin, kadının güçsüz olduğunu simgelediğini, toplumda da sol eli kullanmanın güçsüzlük anlamını taşıdığını belirtir. Sol elin de sağ ele destek olarak yani erkeğe yardımcı olacak şekilde kullanıldığını belirtmektedir (2003 yılında aktaran; Uğurlu, s. 9). Bu sağ ve sol el örneğine tarihin diğer aşamalarında da rastlanıldığı bilinmektedir. Pisagor'un İ.Ö. 6. YY'da düzenlediği "Karşıtlıklar Tablosu”"nda erkek; sağ el gibi güçlü, sağlam ve tablonun iyi tarafinda bulunurken, kadın; hastalıklı, güçsüz ve tablonun kötü tarafinda yer almaktadır (Lloyd, 2015).

Toplumsal cinsiyet kavramının tanımladığı diğer iki önemli kavram da sosyal kişilik özelliklerini belirleyen erillik ve dişillik kavramlarıdır. Bu tanımlama yapılırken; duygusal olma, zayıf olma, birine bağımlı olma gibi özellikler daha çok dişillik özellikleri olarak görülürken; kuvvetli olma, baskın olma, aktif olma, saldırgan ve özgür olma gibi özellikler daha çok erillik özellikleri olarak görülmektedir. Toplumsal cinsiyet, farklılıklar üretir ve devamının sürdürülmesini sağlar. $\mathrm{Bu}$ farklılıklarla da eriller ve dişiller arasındaki eşitsizlik ilişkileri düzenlenmektedir. Bu anlayışa göre toplumsal cinsiyet hem farklılıkların üretilmesini ve devam ettirilmesini hem de eşitsizliklerin üretilmesini sağlar (Wharton, 2005. Aktaran: Erdal; 2010, s.5).

\section{TOPLUMSAL CINSIYYET ROLÜ}

Rol, bireyin toplum içinde sergilediği davranışlarıdır. (Hançerlioğlu, 2000) Toplumsal cinsiyet rolü ise; toplumdaki bireylerin cinsiyetlerine uygun olan davranış şekillerinde davranmaları beklentisidir. Bu kavram genel olarak eriller ve dişiller için toplumdaki bireylerce oluşturulmuş ve uygun görülmüş davranış kalıplarını ifade etmektedir.

Toplumsal cinsiyet rolleri toplumsallaşma süreci içerisinde öğrenilir. Bireyin doğumundan itibaren başlar ve erillik ile dişillik hakkındaki değerler, toplumun en yeni üyesine aktarılır. Toplumsallaşma süreci boyunca toplumdaki bireylerden; toplumca normal kabul edilen, "uygun" davranışları 
görebilmeyi, kendi biyolojik cinsiyetlerine uygun toplumsal cinsiyet rolüne göre davranmay1 öğrenmeleri ve bunu sürdürmeleri beklenir. Erkeklerin biyolojik yapılarından dolayı, erkeklerden sert olmaları, kavgacı ve saldırgan olmaları, aktif olmaları; kadınların biyolojik yapılarından dolayı da kadınlardan narin ve yumuşak olmaları, pasif olmaları beklentisi tarihin eski çağlarından beri süregelmiştir. Bu kalıplar onların toplumsal cinsiyet rollerini belirlemiştir (Ashcraft ve Belgrave, 2005; aktaran: Erdal, 2010, s. 7).

Birey, doğduğu günden öldüğü güne kadar kendisine öğretilen toplumsal cinsiyet rollerine uymak zorundadır. Bunun gerçekleşmesi için üzerinde toplumun oluşturduğu büyük bir toplumsal bask1 vardır. Bu cinsiyet rollerine uygun davranmayı başaramayan ya da davranmak istemeyen bireyler, toplumun uyum sağlamış diğer bireylerince, ki bu toplumun çoğunluğu tarafindan oluşmaktadır, dışlanır. Birey, dışlanmamasını gerektirecek cinsiyet rolleriyle ilgili gerekli bilgileri ailesinden, arkadaşlarından, okuldan, dinden ve dini kitaplardan, özellikle 20. YY ve sonrası için de kitle iletişim araçlarından, en çok da televizyondan bilinçli ya da bilinçsiz olarak öğrenirler (Erdal, 2010).

Toplum, bireylerden beklediği davranışları ödül veya ceza yöntemleri ile pekiştirmektedir (Uğurlu, 2003). Örneğin; erkek ve kadınlardan, karşı cinse ilgi duymaları ve evlenmeleri; toplum ile aile tarafından beklenmektedir. $\mathrm{Bu}$ davranışı/rolü gerçekleştiren erkek, bu davranışından dolayı ödüllendirilir, toplumdaki bireylerce kabul edilir. Tam tersi durumda ise, yani eşcinsel bir davranış gerçekleşmesi halinde, o birey, toplumun beklentilerini karşılayamaz. Bu yüzden de cezalandırılır, toplumdaki bireylerce dışlanır. Burr'a (1998) göre; beklentileri karşılamayan davranışlara getirilen ceza ve yaptırımlar erkekler için daha fazladır (Aktaran: Erdal, 2010, s. 9). Toplumlarda "erkeksi" olan kadınlara bakış ile "kadınsı" olan erkeklere bakış arasında farklılık vardır. Bunun sebebi de günümüzde ataerkil toplum yapısının var olmasıdır. Erkeklerden güçlü olmaları, deyim yerindeyse "adam gibi adam" olmaları, erkekler için belirlenmiș tüm toplumsal cinsiyet rollerini kabul etmesi beklenmektedir. Ataerkil toplumun devamı ve yeniden üretilebilmesi için, erkeklerin belirlenen toplumsal cinsiyet rollerine aykırı davranmamaları bir zorunluluktur.

Toplumsal cinsiyet rolleri doğumdan itibaren öğrenilmeye başlanır fakat bu öğrenme süreci doğum ya da çocukluk dönemiyle sınırlı kalmayan bir süreçtir. Erkek ve kadının sahip olması öğretilen bu roller, bireylerin yaşlarıyla orantılı olarak değişir. Buna ek olarak cinsiyetler arası farklılıkların derecesi de yaş değiştikçe değişmektedir (Erdal, 2010). Çocuklar "erkek çocuk" veya "kız çocuk" rollerine uygun olarak davranmalıdır. Erkek çocuklar kamyon, araba, silah gibi oyuncaklarla yani daha erkeksi oyuncaklarla oynamalıdır. Kız çocuklar ise bebek, mutfak eşyaları gibi oyuncaklarla oynamalıdır. Çocuk ergenliğine ve yetişkinliğe ulaştığında da, her aşama için toplumsal cinsiyet rolleri de değişmelidir (Sigelman ve Rider, 2006; 2010 yılında aktaran: Erdal, s. 10). Ayrıca cinsiyetler arası, yani erkek ve kız rolleri de yaş büyüdükçe daha ayrıksı bir hale gelir. Çocukluk döneminde "sen kızsın, sen erkeksin, böyle davranmalısın" şeklinde aileler tarafından öğretilen roller, ergenlik dönemiyle birlikte iyice ayrışır. Çocukluk döneminde, cinsiyetler her ne kadar farklı olsa da, genel olarak o çocuğun, çocuk olduğu kabul edilir. Ergenlikte olacağı gibi, kız ve erkek çocuk arasında çok büyük bir ayrımsama yapılmaz.

Çocukluktan bir sonraki aşama olan ergenlik döneminde, toplumsal cinsiyet rollerinin kesin ve katı bir şekilde oluşması beklenir. Ergenliğin büyük bir kısmı; erkeğin ya da kadının toplumda hangi davranışlarda, hangi rollerde bulunması gerektiğini daha yoğun bir şekilde öğrenmesiyle ve toplumun bu yöndeki beklentilerine uyum sağlamasıyla geçer. Erkekler; arkadaşları arasında ve karşı cinsteki kişilerce popüler olabilmek için onların dikkatlerini çekmesi gerektiğini öğrenir. Bununla beraber spora karşı ilgili olması gerektiğini ve kadınlara karşı ilgi duyması gerektiğini öğrenir. Bu dönemde aynı zamanda erkeklerin kadınlardan üstün oldukları izlenimi de oluşmaya başlar. Örnek olarak, bir evde ergen bir kız ile ergen bir erkek kardeş varsa; erkek, ailesinden kız kardeşine oranla daha özgür olduğunu, daha üstün olduğunu gözlemler. Bu da ataerkil toplumun yarattığı bir farklılıktır. Kızlar ise dış görünüşlerine özen göstermeleri gerektiğini, erkeklere karşı ilgi duymaları gerektiğini ve olası bir ilişki durumunda namuslarını korumalarının ve duygusal olmalarının gerekliliğini öğrenirler. Namus kavramı devreye girdiğinde kızlar toplumdan daha büyük bir baskı hissederler. Toplumun kadından

Submit Date: 07.05.2018, Acceptance Date: 15.08.2018, DOI NO: 10.7456/10804100/004

Research Article - This article was checked by Turnitin

Copyright (C) The Turkish Online Journal of Design, Art and Communication 
tüm beklentileri namus kavramı çerçevesinde şekillenir. Kadın da bu şekilde roller sergilemeli, namusunu korumalıdır (Carroll, 2010; 2010 yılında aktaran: Erdal, s. 11).

Erkek ve kadının, yılların birikimiyle sahip olduğu, öğrendiği cinsiyet rolleri; ortak bir hayat kurmaya karar verdiklerinde daha ayrıksı bir hale gelir. Örnek verilecek olursa; kadınlar, işi olsun ya da olmasın, erkeğe göre daha fazla ev işi yapar. Bu zaten kendisinden beklenen bir durumdur. Kadından yemek yapması, ütü yapması, çamaşırları yıkaması beklenir. Çocuk doğduğu zaman ise kadının görevleri arasına çocuğunun bakımı da eklenir (Sigelman ve Rider, 2006; 2010 yılında aktaran: Erdal, s. 11).

Erkeklerden toplum tarafindan beklenen "aktif olma, baskıcı olma" rolü evlendiği zaman da devreye girer. Erkek, çocuğuna veya ev işlerine dair olan görevlerinde, kadın kadar sorumluluk üstlenmez. Erkekten iş bulması beklenir. Erkek, evin geçindirilmesi, çalışıp para kazanma gibi görevleri üstlenir. Erkek ve kadın yaşlandığında ise, genç oldukları zamanda olduğu gibi toplumsal cinsiyet rolleri arasında büyük bir ayrım bulunmaz, bazı roller değişmeye başlar. Emekliye ayrılan ve daha çok boş vakti olan erkek, karısına ev işlerinde, varsa torun bakma görevinde daha çok yardımcı olmaya başlar (Carroll, 2010; 2010 yılında aktaran: Erdal, s. 11).

\section{TÜRK SiNEMASINDA KADININ SUNUMU}

Türk sinemasının ilk yıllarından günümüze kadar gelinmiş olan sürede kadınların; ataerkil bir zihniyet çerçevesinde şekillendirildiği görülür. Erkekler her zaman için kadınlardan üstün olmuştur. Zaten 1980’li yıllara kadar olan süreçte, sinemadaki karakterlerin karakter olamadığ 1 görülür. Sadece tek yönlü, kalıplaşmış belirli tipleri meydana getirmektedirler. Bu karakter olamamış tiplerde genellikle sarışın kadınlar iffetsiz, kötü, basit kadın tipleriyle yansıtılmıştır. Üvey anneler de kötü, üvey çocuklarına eziyet eden, koca parası yiyen tipleriyle yansıtılmıştır. Yeşilçam döneminde ise iyi kadınlar faziletli, namuslu ve sevecen, boyun eğen, iyi bir aşık, çocuklarını çok seven iyi bir anne tipleriyle gösterilmiştir. Bunun dişında kalan; yani toplumun beklentilerini karşılayamayan kadınlar da kötü, erkekleri yoldan çıkaran, yuva yıkan, tehlikeli, namussuz gibi tek yönlü ve kalıplaşmış tiplerde sunulmuştur. İyi kadın tipleri filmlerin sonunda mutluluğa erişirken, kötü kadın tipleri de cezalandırılmıştır (Güzel, 2006).

Türk sineması, kadından beklenen toplumsal cinsiyet kurallarını tekrar ve tekrar üretmiştir. Ömer Lütfi Akad'ın 1973 yılında yönettiği “Gelin” filminde Yozgat'tan, İstanbul'a göç etmiş bir aileden bahsedilmektedir. Bu filmde Meryem karakteri kocasını seven, onun için ailesini ve Yozgat'1 terk eden, iyi ve sevecen bir anne olarak filmin ilk sahnelerinde yansıtılmıştır. Kocasının kıyafetlerini ve çoraplarını çıkaran iyi bir eş, "yeri eşinin dizinin dibi, hayatı ve yaşadığı şehir evinin çatısının altında" olan bir karakterdir. Diğer yandan, yaşadığı yer evinin çatısını aşmış, fabrikada çalışmaya başlamış bir kadına kötü gözle bakılmaktadır. Çalıştığı ve evinde oturmadığı, beli ağrıdığı için doktora görünmek isteyen, yani "elin adamına kendini elletmeye meraklı olduğu" için ayıplanmaktadır. Film ilerlediğinde Meryem'in küçük oğlunun çok hasta olduğu ortaya çıkar. Çocuğunun sağlığı için çabalayan anne, bu çabasından dolayı ayıplanır, dışlanır. Evin dışına izinsiz çıkıp doktora gittiği için, altınlarını kocasının dükkanı için değil de oğlunun sağlığı için bozdurduğunda ayıplanır. Hatta kocasından dayak yer. Bu rollerin benzerlerine, Türk sinemasının pek çok yerinde rastlanmaktadır.

Uzun yıllar boyunca kadınların, hikayenin merkezi olduğu konulara yer verilmemiş, kadın karakterler ikinci planda kalmıștır. Yıldız oyuncu sistemiyle beraber bazı kadın oyuncular; toplumsal hayatta ve filmlerde ön plana çıksa bile, yine de hikayenin tam olarak merkezinde yer alamamışlardır. Filmlerdeki hikaye hep erkek karakterler çevresinde ve onların zorlukları, mücadelelerine odaklanmıştır. Yıldız oyuncu sisteminde kadın oyuncular popüleritelerini kaybetmemek için yıllarca hep aynı tipteki ve toplumsal cinsiyet rollerindeki kadınları canlandırmışlardır. Bu da kalıplaşmış kadın karakter rollerinin sürdürülmesini ve yeniden üretilmesini sağlamıştır (Onur, 2012). 
Türk sinemasında kadından bahsedilecekse, kadınla ilişkili en önemli toplumsal cinsiyet rolü kavramı namustur. Kadın evleneceği güne kadar namusunu korumalı, bakire kalmalı, cinsellik yaşamamalıdır. Türk filmlerinde kadın karakterler genellikle boyun eğen, isyankar olmayan özellikleriyle sunulmuştur. Kadın sadece namusu kirletilirse isyan etmelidir. Namusu kirlenmiş bir kadın evlenemez, toplumca dışlanır ve kötü bir şekilde damgalanır. Buna örnek olarak 1962 yılında Metin Erksan'ın yönettiği “Acı Hayat” filmi verilebilir. Manikürcülük yapan Nermin, pedikür yapmaya gittiği kadının oğlu tarafından sarhoş edilir ve onunla ilişkiye girer. Namusu bozulan Nermin, sevgilisinin yüzüne bakamaz. Namusunu kurtarmak için de sevgilisinden ayrılır ve tecavüze uğradığ adamla evlenmeye çalışır. Film ilerler, sevgilisine milli piyangodan büyük ikramiye çıkar, zengin olur. Nermin sevgilisine tecavüz edildiğini anlatır, af diler. Sevgilisi ise Nermin'i yanından kovar. Nermin'e tecavüz eden gencin kız kardeşiyle yakınlaşmaya başlar ve onunla ilişkiye girer. İntikamını alır. Ancak film bitiminde iki genç sevgili kavuşamaz, çünkü Nermin tecavüze uğramış, "kirletilmiş", namusu bozulmuştur. Alınan intikam bile bunu düzeltememiştir. Genç sevgilisi onu reddeder. Nermin de intihar eder. Burada verilmeye çalışılan ileti çok açıktır. Eğer bir kadının namusu, kendi rızasıyla ya da kendi rızası dışında kirlenmişse toplum tarafından dışlanılmalı, bu kirliliği ancak ölümüyle temizlemelidir.

Türk sinemasında kadınların erkeklerle eşit olmadığ 1 ve bunun uzun yıllarca devam ettiği görülmektedir. Eşit olduğu düşünüldüğü zamanlarda bile kadın, her zaman için erkeğin altında yer almış, onun kadar söz sahibi olmamamıştır. Feminist eleştirinin ortaya çıktığı zamanlarda da görülmektedir ki, feminist bakış açısıyla çekilen filmlerde de aslında ataerkil bir bakış açısı her zaman için var olmuştur. Kadınların güçlü olduğu düşünüldüğü yerlerde, o kadın karakterlerin davranışlarını incelemek gerekir. Kadın; erkekler ve toplum tarafından, ancak erkek gibi davrandığı zaman ya da ataerkil sistemin devam ettirilmesine katkı sağladığı zaman önemsenmektedir. Yani kadının gücü; kadın olduğu için değil, ataerkil sistemdeki erkeklerin davranışlarını sergilediği için gelir. Buna örnek olarak; yine Ömer Lütfi Akad'ın 1973 yılında yönettiği “Gelin” filmi verilebilir. Kaynana rolündeki kadının sözü dinlenir, çünkü ataerkil düzenin devamlılığını sağlayacak eylemler gerçekleştirir. Gelinine sürekli bağırır. Evden dışarı örtünmeden çıktığı için onu namusu bozulmuşlukla suçlar. Ataerkil toplum için çok önemli olan namus bekçiliğini yapar. Gelinini itaatsizlikle kısacası ataerkil düzene olan aykırı davranışlarından ötürü yargılar.

1970’li yıllara gelindiğinde, videonun kullanımının artması ve evlere televizyonun girmesiyle sinemaya olan ilgi azalmış, seyirci televizyona yönelmiştir. Bu dönemde Türk sineması büyük sıkıntılarla karşılaşmış ve popüleritesi azalmıştır. Yapımcılar, seyircileri sinemaya çekmenin yolunu düşünmüşler ve $1975^{\prime}$ li yıllarda Yeşilçam seks furyası dönemi başlamıştır (Scognamillo, 2010). Bu dönem tamamen erkeklere hitap edecek şekilde olmuştur. Kadın; erkeği cinsel yönden doyuran bir haz nesnesi olarak sunulmuştur. Bu dönemde kadının ve bedeninin iyice nesneleştiği ve ataerkil toplum yapısında haz verme amaçlı bir köle gibi kullanıldığı görülmektedir.

1980'li yıllara gelindiğinde ise, Türkiye'de yaşanan darbe ile birlikte sinema da değiş̧ir, toplumsal meselelerden çok bireysel konulara yönelir. Sinemadaki kadın da erkek de değişmeye başlar. Artık tek düze tiplerin yerini, zengin bir geçmişe ve hikayeye sahip karakterler alır. Bireyselleşmenin başladığ bu dönemde, kadın karakterler de hikayenin içinde daha çok yer almaya başlarlar. Kadın artık sadece "iyi” ya da "kötü" gibi tek düze değil; daha karmaşık ve geçmişi olan bir karakterdir. Fakat kadın karakterler bu dönemde de önemli olamamış, güçlü görünen kadın karakterler ataerkil düzenin içinde kaybolmuşlardır. Kadınlar daha çok bireysel bunalımları ve kent yaşamı içerisindeki içsel yaşamlarında gösterilmiş, çok az yönetmen tarafindan gündelik yaşam içerisinde sunulmuştur (Scognamillo, 2010). Yavuz Turgul'un “Aşk Filmlerinin Unutulmaz Yönetmeni” filmi buna örnek gösterilebilir. Filmde sadece kadına bakış değil, Yeşilçam sineması ve Türk sineması da eleştirilmektedir. Filmin ana kahramanı aşk filmleri çeken ünlü yönetmen Haşmet Asilkan'dır. Toplumsal gerçekçilikten etkilenerek artık aşk filmleri çekmek istemediğine karar verir ve değişim geçirmek ister. Bu filmde, Yeşilçam döneminin klişeleri, yapım şirketlerinin nasıl olduğu ve amacın sadece para getirecek filmler çekmek olduğu gösterilmekte ve eleştirilmektedir. Buradaki kadın oyuncunun da; filmin odağında olmasa da daha zengin bir karakter olduğu, tek düze tiplerden 
meydana gelmediği görülür. Ayrıca Yavuz Turgul bu filmde, Yeşilçam sinemasındaki kadına bakışı da eleştirmiştir. Filmin bir sahnesinde; teknik elemanlardan biri, kadın oyuncunun yanına gelir ve ona şunu sorar: "Bu filmde oynamak için yönetmenle kaç kez birlikte oldun." Kadın da bu sözün altında kalmaz, tokat atar. Burada, kadınların hem rolü alabilmek için yönetmenle ilişki yaşamaları ve başarıya ulaşmak için cinselliklerini kullanmaları hem de Yeşilçam dönemindeki sinema-yönetmenoyuncu dedikoduları eleştirilmiştir. Filmin sonuna gelindiğinde de, Haşmet başarıya ulaşabilmek için artık toplumsal gerçekçi filmler yapmamaya karar verir ve kendisine gelen aşk filmi çekme teklifini kabul eder. Bu son ile Türk izleyicisinin sinemadan beklentileri de eleştirilmiştir. Bu filmdeki kadın karakter sadece iç dünyasındaki bunalımlarla beyaz perdeye aktarılmamıştır. $\mathrm{Bu}$ filmin kadın karakteri, gündelik yaşam içerisinde seyirciye sunulmuştur.

21. YY'a gelindiğinde ise kadınların; Yeşilçam imgelerinin dışında, yeni imgelerde ve daha özgür oldukları görülür. Cinselliği artık özgürce yaşayabilmekte, ahlakçı ve namusçu bakış açısının katı kurallarının dışına çıkabilmektedirler. Ancak, bu dönemde kadınlar için değişmeyen şey ise özne olamamaları, ataerkil düzenin içindeki hikayelerde yer almaya devam etmeleridir. Kadın hala filmlerin odağında yer alamamakta; özellikle popüler gişe, erkek filmleri arasında sönüp kaybolmaktadır. Kadın karakterlerin sinemadaki en büyük işleviyse; erkek karakteri harekete geçirecek olayların başlamasını sağlamaktır. Zeki Demirkubuz'daki kadın karakterler genellikle kötüdür ve olayların başlamasına yardımcı olur. 2001 yılı yapımı "İtiraf" filmindeki kadın karakterin, kocasıyla arasındaki gerilimi başlatıp, bir de sessiz kalarak ikisi arasındaki gerilimi iyice arttırması gibi. Buna benzer bir örnek Nuri Bilge Ceylan'ın 2014 yapımı "Kış Uykusu" filminde de verilebilir. Erkek karakter hem karısıyla hem de kız kardeşiyle sorunlar yaşamaktadır ve her iki kadın karakter de olayların başlatıcısı olarak kalmakta, onlarla ilgili daha derine inilmemektedir.

\section{MUSTANG FILMININ TOPLUMSAL CiNSIYET ROLLERİ AÇISINDAN ANALIZİ}

“Mustang" filmi, 97 dakika uzunluğunda, 2015 yapımı olup; yönetmen Deniz Gamze Ergüven'in ilk uzun metrajlı filmidir. Filmin senaristliğini Deniz Gamze Ergüven'in ve Alice Winocour'ün üstlendiği Mustang; Fransa, Türkiye, Almanya ve Katar ortak yapımı bir filmdir. Filmin yapımcısı Charles Gillibert'tir. Filmin diğer teknik ekibi ise şöyledir ("Mustang”, ty.):

Görüntü yönetmenleri: David Chizallet ve Ersin Gök

Sanat yönetmeni: Serdar Yemişçi

Kurgu: Mathilde Van de Moortel

Ses: İbrahim Gök

Müzik: Warren Ellis

Oyuncular: Güneş Şensoy, Doğa Doğuşlu, Elit İşcan, Tuğba Sunguroğlu, İlayda Akdoğan.

Filmin ilk gösterimi 19 Mayıs 2015'de Cannes Film Festivali'nde yapıldı ("Mustang”, 2015). 88. Akademi Ödülleri'nde ise Fransa adına yabancı dilde en iyi film dalında aday oldu. Diğer film festivallerinde filmin toplamda 56 adaylığ 1,39 tane de ödülü vardır ("Mustang”, ty.). Fransa"da 17 Haziran 2015'de vizyona giren film, Türkiye'de ise 23 Ekim 2015 tarihinde gösterilmiştir.

4 Haziran 1978 Ankara doğumlu Deniz Gamze Ergüven; çocukluğunda Fransa'ya taşınıp orada yaşamıştır. 2008 yılında "La Fémis" isimli sinema okulundan mezun olmuştur. Mustang; yönetmenin çektiği ilk filmdir. Film, ilk kez Cannes Film Festivali’nde gösterilmiştir. 2016 yllı itibariyle de "Sinema Sanatları ve Bilimleri Akademisi (AMPAS)"'n üyesidir ("Deniz Gamze Ergüven Biography", ty.). 
Film; öksüz kalmış 5 kız kardeşi (Sonay, Selma, Nur, Lale ve Ece) anlatmaktadır. Öksüz kaldıkları için babaanneleri ve dayılarının evinde yaşamakta, onların kurallarıyla dolu bir dünyaya uyum sağlamak zorundadırlar. Okulların tatil olduğu gün, sınıftaki erkek arkadaşlarıyla denizde oyun oynayan kızların başı, komşularının onları erkeklerle oynarken görmesi yüzünden belaya girer. "İnsanlar ne der" diye kaygılanan babaanneleri, kızların evden dışarı çıkmasına izin vermeyecek, onlara namuslu ve iyi bir kızın nasıl olduğunu öğretecektir. Kızların hayatları cehenneme dönecektir. Babaannesi bununla da kalmayacak; kızların namusu elden gitmeden, küçük yaşlarına rağmen onları evlendirmeye başlayacaktır. Kızlar da, bu baskıcı durumla başa çıkmaya çalışacaklar, ergenliğin verdiği isyankar duygularla isyan edip özgürlüğü arayacaklardır.

"Mustang" filminde hareketli bir kamera kullanımı tercih edilmiştir. Hareketli kamera ile; karakterlerin yaşadığı sallantılı hayat, ve bu hayat sonucundaki sallantılı psikolojileri yansıtılmıştır. Karakterlerin durağan olduğu, durağan sahnelerde bile kamera hareketli olmuştur. Bu ise; kamera ile sahnedeki aksiyon arasında bir tezatlık oluşturmuştur. Kamera; sanki birileri, beş kız kardeşi takip ediyormuş gibi hareket etmektedir. Takip sahneleri oldukça fazladır. Bu ise; filmde anlatılmak istenen toplumsal cinsiyet rollerini; toplumun kadınlar üzerindeki etkisini yansıtmaktadır. Toplum; kadınları her zaman izlemekte, takip etmektedir.

Filmde; daha çok bel ve omuz çekim ölçeği kullanılmıştır. Bu ölçeklerle; karakterlerin hem psikolojileri gösterilmiştir hem de karakterlerin yaşadığı çevre tanıtılmıştır. Filmdeki karakterlerin yaşadığı çevrenin, psikolojileri üzerinde yoğun bir etkisi olduğu için, bu açı kullanılmıştur. Filmde yakın ve detay çekimler de kullanılmıştır. Yakın çekimler ile, karakterlerin yaşadı ğı çevre etkisini yitirmiş; karakterin iç dünyasına odaklanılmıştır (Monaco, 2013). Geniş planlar ise; karakterlerin yaşadığ1 çevre tanıtılırken kullanılmıştır. Film; 5 kız kardeş üzerine olduğu için, beşinin de toplu olarak gösterildiği çekim ölçekleri fazladır. Toplu çekimler ile; karakterlerin yaşadıkları şeylerin aynı olduğu ve aralarındaki sevgi gösterilmek istenmiştir.

"Mustang" filminde genel olarak doğal 1şık kullanılmıştır. Gündüz sahnelerinde mekanın doğal ışığ1 kullanılmış; gece sahnelerinde ise dramatik aydınlatmanın fazla kullanılması tercih edilmemiştir. Gece sahnelerinde aydınlatma; masa lambası, el feneri, arabanın ışıkları, sokak ışıklarının odaya vurduğu yansıma ile yapılmışıtır.

"Mustang" filmi kronolojik sırayla ilerleyen bir filmdir. Filmde genel olarak düz kurgu yapılmış; iki sahne kesmelerle, kararma ve açılmalarla birbirine bağlanmıştır. Bunun dışında, kızların maça gittikleri sahnede; stadyum ile evleri arasında paralel kurgu da yapılmıştır. Paralel kurguda; aynı anda gerçekleşen birden fazla olay kurgulanarak anlatılır. (Bordwell ve Thompson, 2012) Kızlar stadyumda maçtayken, aynı anda da babaanneleri ve komşuları televizyonda kızları görmektedir. Filmin, sadece sonlarına doğru bir adet flashback sahnesi gösterilmiştir. Bu yapılan flashback kurgusuyla da; kızların artık özgür olduklarına vurgu yapılmış, sahnenin dramatikliği arttırılmıştır. Filmde; doğal, canlı ve parlak renkler kullanılmıştır. Canlı ve parlak renklerin kullanılması da; karakterlerin ruh halleri ve tutsak gibi olan yaşamları ile bir tezatlık oluşturmaktadır.

"Mustang" filminin büyük bir çoğunluğu; karakterlerin hapis hayatı yaşadıkları evlerinde geçmektedir. Filmin başında; kızların eğitim gördükleri lise, köylerindeki deniz, İnebolu ilçesindeki çeşitli merkezler, Yasin karakterinin arabası, hastane, otogar ve mezarlık filmde geçen diğer mekanlardır. Filmde ayrıca, İnebolu'nun uçurumlu sahil şeridi yolu da gösterilmiştir. Bununla; İstanbul'a gitme hayalleri kuran karakterlerin, aslında kaçamayacakları; çevrelerinin, sınırlarla ve uçurumlarla çevrili olduğu mesajı verilmiştir. Uçurumlar ve sınırlar ise; topluma ve toplumun kızlar üzerindeki baskılarına, engellerine işaret etmektedir.

"Mustang" filminde; koyu tonlarındaki geleneksel kıyafetler kostüm olarak kullanılmıştır. Bu geleneksel kostümler ise; toplumu simgelemektedir. Toplumun isteklerinin ve namusun simgesi olan bu kıyafetler, kızlara zorla giydirilmeye çalışılmıştır. Bunun dışındaki parlak, renkli, açık, canlı kostümler ise; kızların ahlakları bozulabilir diye, filmin ilk dakikalarında dolaba kapatılmıştır. 
Dekorlara bakıldığında ise; geleneksel Türk evinde bulunan dekorların olduğu görülmektedir. Televizyonun üzerindeki danteller ile evdeki geriye kalan tüm eşyalar; geleneksel evler ile uyum sağlamaktadır. Dekorlarda bir de şu detay görülmektedir: Babaanne, kızların eşyalarını kilitlediği dolabi açtığında; bir kıyafetin üzerinde "\#direngezi” yazmaktadır. Yönetmen bu dekorla, Gezi Parkı olaylarına gönderme yapmıştır.

"Mustang" filminde genel olarak, sahnenin geçtiği mekanın doğal ortam sesi kullanılmış; film için bestelenen instrümental müzikler de sahnenin dramatikliğini artırmak için kullanılmıştır. Bunun dışında; kına gecesi sahnesinde, geleneksel kına gecesi müziği olan "Yüksek yüksek tepelere" şarkısı karakterler tarafından söylenmiştir. Bu şarkıyla Türklerin, kına gecesi adetleri seyirciye yansıtılmıştır. Ayrıca; düğün sahnelerinde oyun havası müzikleri kullanılmıştır. Bunun dışında; kızların evden kaçıp stadyuma gittikleri sahnede çalan müzik; kızların sahip oldukları güzel duyguların arttırılmasında ve seyircilerin, onlar için mutlu olmasında etkili olmuştur.

\section{MUSTANG FÍLMI ÇÖZÜMLEMESI}

Filmin adının, yani Mustang'ın anlamı şudur: Genelde Amerika'nın batı eyaletlerinde, sahipsiz, başıboş gezen yabanileşmiş at, yabani at ("Meaning of "mustang" in the English Dictionary", ty.). Ergenliğine daha girmemiş ya da yeni girmiş 5 tane kız düşünülürse, bu isim anlamlı gelmektedir. Çünkü ergenlik dönemi; kız ve erkeklerin büyümeye başladığı, hormonlarının değiştiği bir dönemdir. Bir o kadar da gergin, sinirli ve asi oldukları, kısaca vahşileşebildikleri bir dönemdir. Bu dönemde kimseyi dinlemek istememe, başına buyruk davranma halleri görülür. 5 kız; "namus elden gidiyor, insanlar ne düşünür" düşüncesi altında hapis hayatı yaşamaya başlar. Bu duruma karşı da kendilerince direnmeye çalışırlar. Tıpkı at yelesi gibi olan upuzun saçlarını; hapis hayatı gibi geçen ergenlik günlerinin ilk zamanlarında, tutsak edildikleri evde ve hayatta sallandırırlar. Kızlar "Mustang" gibidir. Vahşi, upuzun saçlı ama tutsak. Tıpkı ehlileştirilmeye, tutsak edilmeye çalışılan yabani bir at gibi. Doğada özgürce koşarken; özgürlüğü insanlarca kısıtlanmış, ağıla kapatılmış bir at gibi. Ayrıca Mustang; yani at, Türkler için çok önemli ve çok değerlidir. "At, Avrat, Pusat" terimleri Türk milleti için tarihin ilk dönemlerinden bu yana hep önemli olmuştur. Atın kuyruğunu kesmek ya da herhangi bir şekilde ata zarar vermek; kadına dokunmak, iffetine göz dikmek büyük bir hakaret kabul edilirdi. $\mathrm{Bu}$ hakaretin temizlenmesi için de pusada başvurulurdu.

Göçebe Türk kabileleri, bir yerden bir yere göç ettikleri zaman bir tek atlarını, kadınlarını ve silahlarını geride bırakmayıp yanlarında götürürlerdi. Ayrıca "At, Avrat, Pusat" sözcükleri Türklerin mülkünde bulunan en önemli şeylere gönderme yaparken; bir de ataerkil düzenin söylemlerinden birine de gönderme yapmaktadır. Bu yüzden; Mustang kelimesinin, yani atın, bir ataerkil düzene ve onun düzeni içinde yaşayan 5 kıza gönderme yaptığı düşünülebilir. At; bir bakıma namusu ve temizliği, sadakati simgelemekte; at gibi bir hayvana zarar gelmesi durumunda namus davaları baş gösterebilmekte, atları için her şeyi yapabilmekteydiler. Bir kadının (avratın) namuslu olması ise ataerkil düzende kadından beklenen en önemli ve en katı roldür.

Film; Karadeniz'in kıyı kesiminde, dağların arasında, yemyeşil, doğayla iç içe bir köyde geçmektedir. Yaz tatili olur. Anne ve babaları vefat etmiş beş kız kardeş okuldan karnelerini alıp çıkarlar. En küçük kız kardeş Lale'nin en sevdiği öğretmeni de İstanbul'a taşınacaktır. Lale ağlayarak, öğretmenine veda eder. Kızlar; eve gitmeden önce denize gitmek ister. Bu sırada erkekler de kızların yanına gelir ve denizde su güreşi yapmaya başlarlar. Kızlar erkeklerin omuzlarına çıkar, güreşmeye başlarlar. Deniz dönüşü, komşularının elma bahçelerinden geçerler. Gizlice, ağaçtaki elmaları koparıp yerler. Bunu gören komşuları; elinde silahla, koşarak gelir. Kızları bahçesinden kovar. Bu sahne; Adem ile Havva efsanesine benzetilebilir. Adem ile Havva, yılan şekline bürünmüş şeytanın akıllarını çelmesiyle; yasak elmayı yerler. Allah/Tanrı tarafından da cennetten kovulurlar. Kızlar da yasak elmayı yemiş; erkeklerin omuzlarına çıkıp, kendilerinden beklenen rollere aykırı davranmışlardır. Komşuları da; kızları, bahçesinden pusat ile kovmuştur. Bu sahneden sonra kızların cennet hayatı biter. Dünyaya gönderilirler. Artık filmin giriş bölümü biter. Olayların başlamasını sağlayacak çatışma bölümüne geçilir. 
Kızlar eve gülerek, mutlu bir şekilde döner. Fakat ortada büyük bir sorun vardır. Babaannelerinin komşusu; kızları, erkeklerin omuzlarında görmüştür. Babaannelerine "namus elden gidiyor" diyerek şikayet etmiş̧ir. Babaannelerinin komşusuna göre; kızlar, ergenlik dönemindeki kızların davranması gerektiği şekilde davranmamışlardır. Toplumsal cinsiyet rollerine uygun olarak beklenen şekilde davranmamışlardır. Babaanneleri kızları teker teker döver. Aklından geçen tek bir şey vardır: bu kızlar toplumun beklentilerine göre davranmayıp; yabani bir at gibi, başlarına buyruk davranmışlardır. Toplum duysa kızlar hakkında ne düşünür, en önemlisi babaanneleri hakkında ne düşünür. Hatta babaanneleri şöyle demiştir: "Herkesin diline düşürdünüz bizi, rezil ettiniz." Babaannelerine göre, o yaşlardaki kızların, erkeklerin omzunda olması; kendilerini tatmin etmeleri anlamını taşımaktadır.

Kızlar; komşularının kendilerini ispiyonladığını öğrendiklerinde isyan eder. Şiddetle evden çıkıp, komşularından hesap sormaya giderler. Lale; komşusuna: "Giydiğiniz o kiyafetlerle kendinizi ahlak yetkilisi mi sandınız." diyerek isyan eder. Hesap sorar. Komşusu; gri renkli, sade bir kıyafet giymektedir. İlerdeki sahnelerde kızlara da giydirilecek bu kıyafetler; ataerkil düzenin giydirdiği rollerin kıyafetidir. Komşuları da; sanki, gece bekçisinin üniforma giyerek, bekçilik yapması gibi davranmıştır. Gri kıyafetiyle; kızların namus bekçiliğini yapmaktadır.

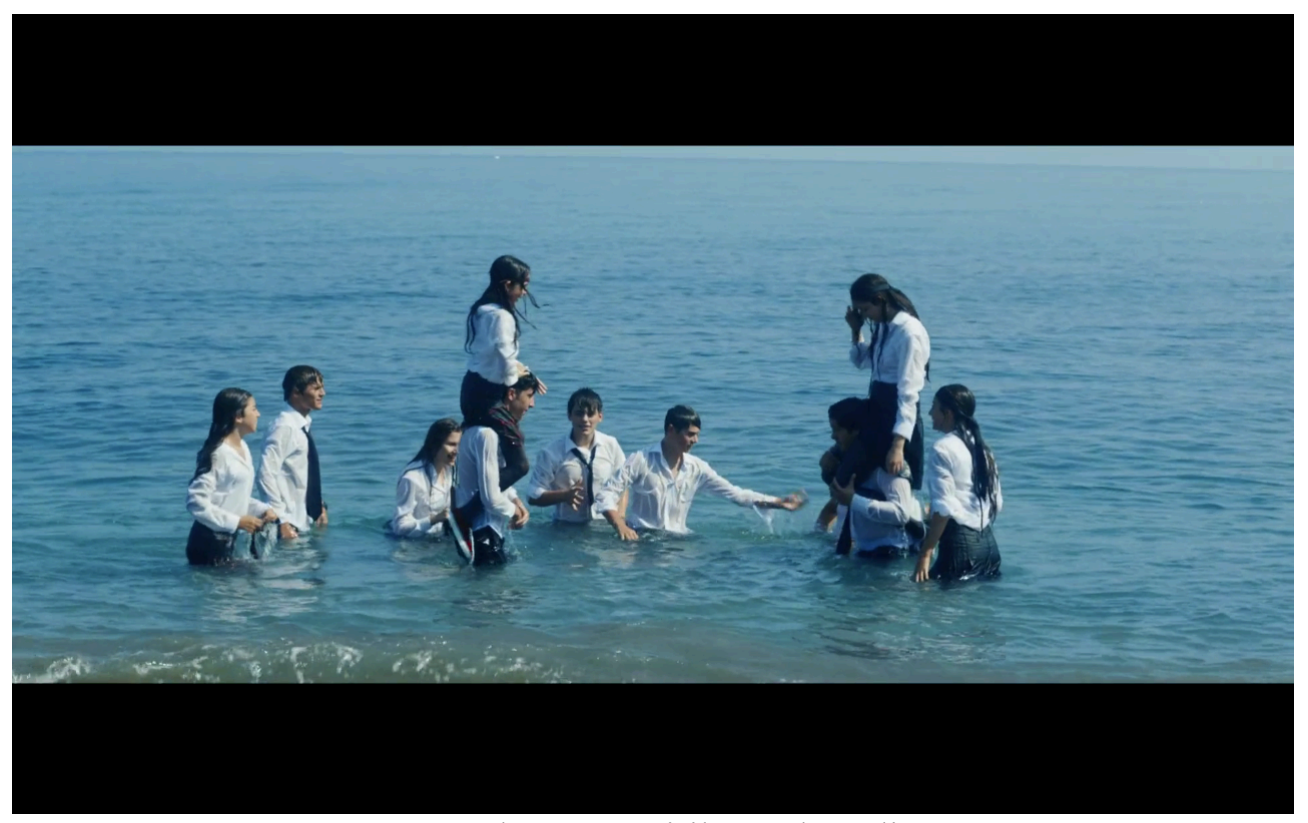

Sahne 1. Serbestçe Geçirilen Eğlenceli Zaman

Blank (2008) şöyle demektedir: "Bir kızın evlenmeden bekaretini kaybetmesi; açıkça ataerkil olan eski dünyada, hem aileyle kızın kendisinde utanç verici bir denetim eksikliği, hem de kızın babasına karşı işlenen bir mal suçu oluşturmaktaydr." "Namusları elden gitti, kendilerini tatmin ettiler, bekaretleri bozuldu, herkes ne düşünür" düşüncelerinin sonucunda amcaları; kızlara şiddet uygular. Kızları hastaneye götürür. Bekaret testi yaptırır. Burada; bekaret ve namus kavramının Türk toplumu için ne kadar önemli olduğunu görmekteyiz. Çünkü bekaretini evlenmeden önce kaybetmiş bir kadın; beklenen toplumsal cinsiyet rollerine aykırı davranmış demektir. Böyle bir durumda da kadın dışlanır, iffetsiz sıfatıyla damgalanır ve evlenebilmesi bile mucize haline gelebilir. Kızların babaanneleri de, bekaret raporunu görünce şunları söyler: "En ufak bir şüphe bile olsa asla evlenemezdiniz." Kandiyoti (2015) şöyle demektedir: "Kadınlara; herhangi bir yanlış davranış nedeniyle bütün bir topluluğa, sülaleye ya da aileye utanç ve şerefsizlik getirecek denli muazzam olumsuz bir güç atfedilmiştir. Bu nedenle; tamamen eve kapatılma ve örtünmelerinden, kamusal alana girişlerinin ve hareketlerinin sinırlandırllmasına kadar varan, katı dışsal baskılar altında yaşarlar."

Babaanne de; kendi oğlunun sözlü şiddetinden nasibini alır. Torunlarını korumaya çalıştığı için; oğlu, annesine bağırır. Ertesi gün komşusuna dert yanan babaanneye, komşusu şöyle der: "Kızmakta haklı. 
Demek ki sen de babaanneliğini yapamadın.” Burada iki şey görülebilir. Birincisi; ataerkil düzenin istediği şekilde davranan; o rollerin devam ettirilmesi için çabalayan bir kadın. (Komşu. Bu kadın; rollerini iyice benimsemiştir.) İkincisi de; torunlarına namus dersleri vermeyi başaramadığ 1 için ayıplanan bir babaanne. Selma'nın hastane dönüşü söyledikleri de anlamlıdır: "Doktor bana; kadınların neye benzediğini senden öğrenmeyeceğim, dedi. Sonuçta haksız da sayılmaz. Hepimiz aynıyız." Burada açık bir şekilde; ataerkil ideolojinin, kadınlar ve erkekler arasında yarattığı eşitsizlik görülmektedir. Kadınlara; erkeklerden daha değersiz oldukları, her yolla öğretilmektedir. Kadınlar da kendilerini; olduklarından daha basit görmektedir. Selma da kendisini; diğer kadınlarla benzer görür.

Hastaneden döndükten sonra, evde büyük değişiklikler başlar. Bu yaşlardaki Türk kızlarından ahlaklı olmaları beklenmektedir. Bu yüzden de; evde, kızların ahlaklarını bozabilecek her türlü şey yok edilir, yasaklanır. Parıltılı elbiselerden, şort ve eteklere; makyaj malzemelerinden, bilgisayar ve telefona kadar; kızların ahlağını bozabileceği düşünülen her türlü şey bir dolaba kilitlenir. Dışarıya dayıları ya da babaanneleri olmadan çıkmaları da yasaklanır.

Sonra kızlara nasıl edepli, namuslu, hamarat; kısacası ideal ev kadını olunur, öğretilmeye başlanır. Türk toplumunda kadınlar; nasıl ideal bir ev kadını olacaklarını çocukluk zamanlarından öğrenmeye, bu kimliği edinmeye başlarlar. Bu kimlik aynı zamanda kitle iletişim araçları yoluyla da verilmektedir. Ev işlerini yapmayı beceremeyen kadınlar ise, toplumun beklentilerine aykırı davrandığı için dışlanır; "Sen nasıl evleneceksin? Evde kalacaksın" gibi sözler söylenir. Torunlarının da evde kalmasını istemeyen babaanne; kızlara dolma nasıl yapılır, hamur nasıl açılır, börek ve mantı nasıl yapılır gibi şeyleri öğretmeye başlar. Öğrettikleri de yemekle sınırlı kalmaz. Yorganın içine nasıl pamuk doldurulur, temizlik nasıl yapılır, cam nasıl silinir, bu tarz şeyleri de onlara öğretir.

Daha sonra kızları ahlaklı gösterecek geleneksel kıyafetler dikilir. Kıyafetlerin renkleri gri, siyah ya da kahverengidir. Türk toplumunda, özellikle kırsal ve doğu bölgelerde, kadınların nasıl giyinmesi gerektiğine dair toplumsal cinsiyet rolleri bulunmaktadır. Örneğin kadınlar; çok açık, çok parıltılı giyinmemeli, kısa etek giymemelidir. Böyle giyinen kadınlara, toplum tahammül edemez. Toplum; kıyafet ile namus arasında da bir ilişki kurmaktadır. Çok açık giyinmiş kadınlara namussuz ve iffetsiz gözüyle bakılmaktadır. Filmde yönetmenin, geleneksel kıyafet dikimi sahnesini göstermesi, bu toplumsal rol beklentilerine ve toplum tarafindan oluşturulmuş; kıyafet ile namus arasında kurulan değişik ilişkiyi göstermiştir. Ayrıca; buradaki geleneksel kıyafetler; toplumun kendisini simgelemektedir. Toplumun beklentilerini, toplumun normlarını ve yasaklarını yansıtmaktadır. Kızların üzerine zorla giydirilen bu kıyafetler gibi; toplumsal cinsiyet rolleri de, toplumdaki bireylere zorla giydirilmeye çalışılmaktadır. Yemek dersleri bittiğinde, odalarına koşan kızlar; üzerlerindeki bu kıyafetleri iğrenerek çıkarır. Sonay; eline makas alarak geleneksel kıyafetinin bacak bölgesini yırtar. $\mathrm{Bu}$ yırtık, daha sonra babaanesi tarafından dikilecektir. Sonay, evden dışarı çıkamadığı için; erkek arkadaşıyla buluşmak için evden gizlice kaçar.

Sakız çiğnemek bile dayıları tarafından kabul edilmeyen bir davranıştır. Hastaneye bekaret kontrolü yapmaya gittiklerinde; hastane avlusunda erkek hemşireler bulunmaktadır. Amcası sert bir şekilde Lale’ye ağzındaki sakızı çıkarmasını söyler. Sakız çiğnemek, özellikle bazı ataerkil halklarda iffetsizliğin çağrıştırıcısı olabilmektedir. Bu yüzden sakız kızlara şiddetle yasaklanır. Bu yasak karşısında kızlar; ev yapımı sakız yaptıklarında ve gizli gizli çiğnediklerinde sevinecek hale gelirler.

Kızlar evdeki baskıdan iyice bunalmaya başlarlar. Bir gün evde kimse yokken, en küçükleri Lale, sütyeninin içine pamuk ve çorap doldurarak dans etmeye başlar. Burada iki şey görülebilmektedir. Birincisi, küçük bir kızın yetişkin bir kadın gibi davranma isteği. Bu; pek çok küçük çocukta görülebilen bir davranıştır. İkincisi ise toplumda kadından beklenen cinsiyet kimliğine uygun bir davranış görülmektedir. Erkeklerin kadınlardan beklediği de böyle bir şeydir; iri göğüsler. Günümüzde pek çok televizyon programında ya da sinema filminde bunun topluma aşılanmaya çalışılan bir görüş ya da kadından beklenen bir beklenti olduğunu görülmektedir. Pek çok kadın, kocasının beklentilerini karşılayabilmek adına estetik ameliyat yapmaktadır. Lale de sütyeninin içine pamuk koyarak, göğüslerini irileştirmeye çalışmaktadır. Bu yüzden de ataerkil düzenin beklentilerini sergilemektedir. 
Tabi oynadığı bu oyun, evin içinde kimse olmamasına rağmen babaannesini rahatsız eder. Babaannenin aklında "ya eve biri gelirse" düşüncesi vardır. Bu yüzden de Lale'nin uzun zamandır yaptığı tek eğlencesi de yarıda kalır.

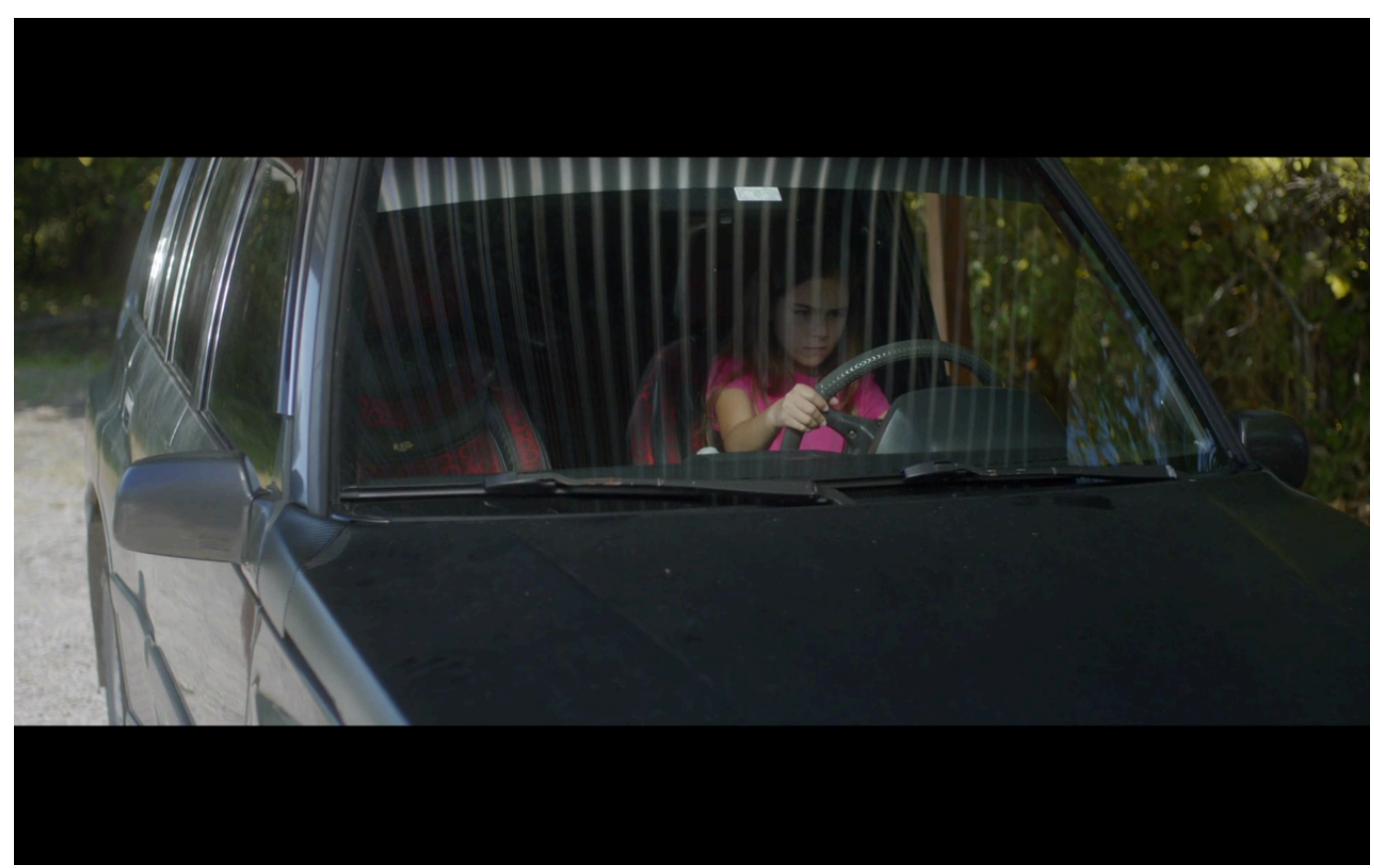

Sahne 2. Sürüş Sırasında

En küçük kız Lale incelenecek olunursa; Mustang'a, yani yabani ata en fazla benzeyen karakter olduğu görülebilir. Diğer kardeşlerinin sorgusuz sualsiz kabul ettiklerini Leyla sorgulamakta, zorluk çıkarmaktadır. Başına buyruk davranabilmesi daha olanaklı bir karakterdir. Örneğin kardeşini istemeye geldiklerinde kahvenin içine tükürür, kurabiyeleri yere döker. Bir örnek daha verilecek olunursa; Leyla futbolu çok sevmektedir.

Maçı canlı olarak stadda izlemek için amcasından izin ister. Fakat amcası; "orası senin yerin değil" diyerek, Leyla'nın bu isteğini reddeder. Yine bir gün evde kadınlar mutfakta oturmakta, yemek yeyip dizi izlemektedir. Erkekler de bahçede maç izlemekte ve rakı içmektedir. Leyla maça bakmak için erkeklerin bulunduğu yere gittiğinde, amcası ona kötü bakışlar atar. Leyla'nın erkeklere özgü bir şeyden zevk alması ve bu yüzden erkeklerin yanına gitmesi onaylanmamaktadır. Futbol, erkek cinsiyet rolüne uygundur, kadınlar için değildir. Kadınlar bu cinsiyet rolünü üstlenmeye çalıştıklarındaysa kabul göremezler.

Trabzonda maç yapılacaktır. Önceki maçtaki taraftarlar olay çıkardığı için; maça sadece kadınların katılmasına izin verilir. Televizyon ekranında bu olayla ilgili haber yapılır. Spiker şunu demektedir: "Kadınlar da bu işi neden yapmasınlar?" Burada aslında, toplumsal cinsiyet rollerine ve beklentilerine de bir eleştiri yapılmaktadır. Amcasının düşündüğünün aksine; kadınlar da futbol'a gidebilir.

Leyla, futbol maçına gitmeyi çok istemektedir. Baş kaldırır, kardeşlerinin de aklını çeler. Zaten evde iyice bunalan kızlar, maça gitmek için evden kaçıp otobüse biner. Trabzon'a giderler. Babaanneleri de kızları; televizyonda izler. Bütün köy bu durumu öğrenmesin, babaanne mahcup olmasın diye; Emine halaları bütün köyün elektriğinin kesilmesini sağlar. Bu firarlarının bedeli ise oldukça ağır olur. Toplumsal cinsiyet rollerine göre bir kızın evden kaçması büyük sorunlar oluşturmaktadır. Eve işçiler gelir, kızlar bir daha kaçamasın diye kapılara demir parmaklıklar dikilir.

Bu olaylar olurken, babaanneleri torunlarını köy meydanına götürür. Kızların üzerinde yine geleneksel kıyafetleri vardır. Dışarıya çıkışları ancak edepli görünebilecekleri kıyafetlerle mümkün olmaktadır. Köy meydanına gitmelerindeki amaç ise; babaannelerinin onları sanki bir malmış gibi, meydanın

Submit Date: 07.05.2018, Acceptance Date: 15.08.2018, DOI NO: 10.7456/10804100/004

Research Article - This article was checked by Turnitin

Copyright (C) The Turkish Online Journal of Design, Art and Communication 
ortasında, potansiyel alıcılara sergileme isteğiydi. Babaannelerinin aklında tek bir düşünce vardır: "Şu kızlara koca bulmalı ve bir an önce de evlendirmeli."

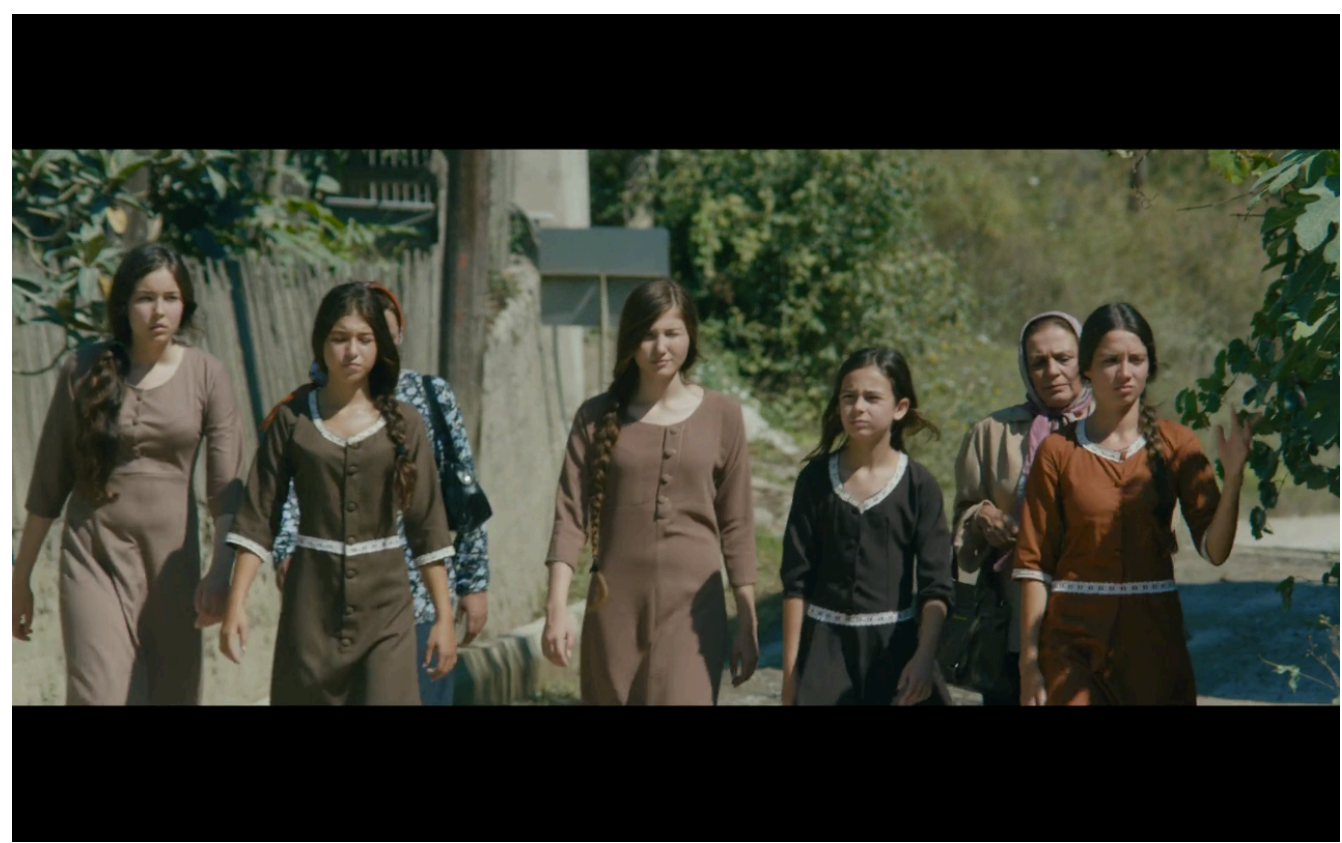

Sahne 3. "Edebli” Kıyafetlerle Yürüyüş

Sonay için eve görücüler gelir. Sonay başka biriyle evlenmek istediği için; babaanne, eve gelen görücüyü eli boş göndermez. Görücüye Selma'yı ayarlar. Kız bu duruma bir şey söyleyemez. Çünkü büyükler buna karar vermiştir. Toplumsal cinsiyet rolleri bunu buyurmaktadır. O role uygun davranmak zorundadır. Görücüyü reddetmek ya da evlenmemek; kızın ailesi tarafından reddine sebep olabilir. Babaannesi, düğünün hemen yapılmasını istediğinde; damadın ailesi şaşırır. Fakat en sonunda onlar da kabul ederler. Ardından da Sonay için görücü gelir.

Düğün öncesi babaanne, kızların eşyalarını kilitlediği dolabı açar ve içinden "Cinsel Hayatım” kitabını alır. Selma'ya verir. Burada amaç; gerdek gecesinde yaşayacağı ilişkiyle, kocasını nasıl tatmin edeceğini, nasıl sabırlı olacağını öğrenmesidir. Daha sonra kına gecesi yapılır. Bu kına gecesi, Türklerin kına gecesi geleneklerini yansıtmaktadır. Kına gecesinden sonra düğün gecesi gelir. Sonay, sevdiği adam ile evleneceği için mutludur. Selma ise; mutsuzluğundan, bütün rakıları içer, sarhoş olur.

Selma için gerdek gecesi vakti gelir. Kandiyoti (2015) şöyle demektedir: “ Kadın cinselliği üzerindeki toplu denetimin önemli bir nedeni kadının cinsel iffeti ile aile ya da sülalenin şerefi arasında kurulan bağlantıdır. "Kandiyoti'nin sözü, filmde şu örnekle desteklenebilir: Düğün sonrası, damadın annesi ve babası kapıda beklemektedir.

Bekleme amaçları ise; kanlı çarşafı görmektir. Çarşaf asma geleneğinde olduğu gibi; gelinlerinin namuslu ve bekar olduğunu görmek ve herkese duyurmak istemektedirler. Çarşafta kan göremeyince, Selma'yı hastaneye götürürler. "Oğlumuzu evlendirdik, çarşafı göremedik" der kaynana. Kandiyoti'nin dediği gibi: “...kadının cinsel iffeti ile ailenin şerefi...” Babanın belinde de bir tane silah vardır. Türklerin kullandığı kelimeler gibi: "At, Avrat, Pusat”. At, yani Mustang; namusa, temizliğe ve sadakate (kadının iffetli olmasına) gönderme yapmakta, Avrattan da namuslu olması beklenmektedir. Çarşaftaki kanı göremeyen kaynana ve kayınpeder, avratın namusundan şüphelenir. Türklerin değer verdiği üçüncü şeye; yani silaha/pusada sarılır. 


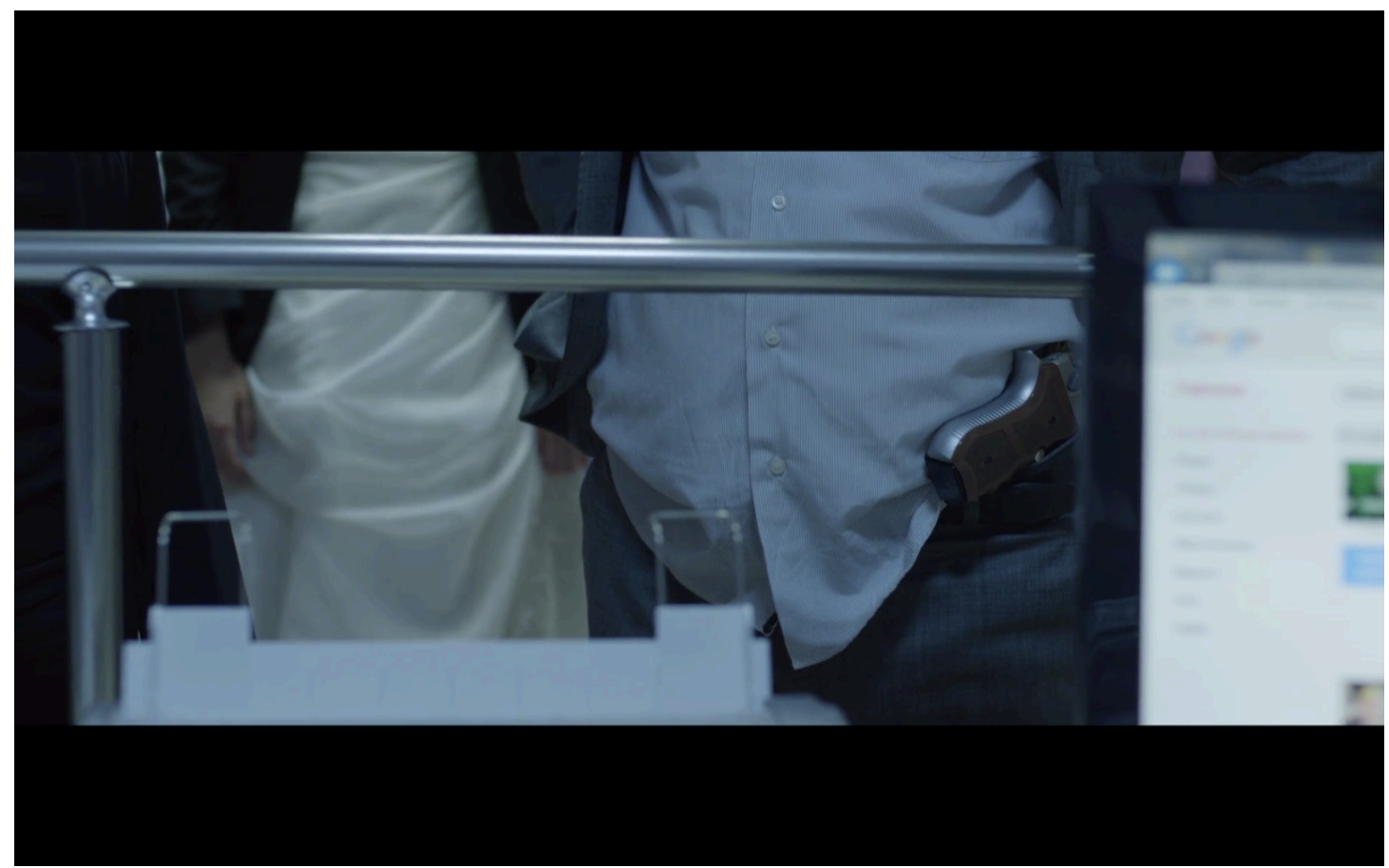

Sahne 4. Silah İle Tehtid

Selma bekaret muayenesi olur. Muayene olurken kamera; Selma'ya yukardan bakar. Selma'yı öyle bir gösterir ki, sanki Selma tabutta, ölü bir şekilde yatmaktadır. Bu muayene, Selma'nın hayatı için önemlidir. Bu sırada doktora, dünyadaki herkesle yattı̆̆ını söyler. Ama muayene sonucu bunun mümkün olamayacağ 1 , tıbbi bir durum olduğu anlaşılır. Selma der ki: "Bakire olduğumu söylediğimde hiç kimse inanmıyor bana." Burada; toplumun bazı kadınlara karşı olan önyargıları görülebilmektedir. Bazı kadınlar; görünüşleri, giyinişleri ya da davranışlarından dolayı namussuz ya da iffetsiz olarak damgalanabilmektedir. Burada da, Selma'nın görünüşü ve hareketleri dolayısı ile; bu damga kendisine kolayca yapıştırılmıştır. Hatta kardeşleri bile bekar olduğuna ilk başta inanmak istememişlerdir. Bunun sebebi ise; gelinin, kendisinden beklenen toplumsal cinsiyet rollerine biraz da olsun uymamay tercih etmesidir. Bu yüzden dış görünüş olarak kolayca dışlanıp damgalanabilmektedir.

Babaanne, 2 torununu evlendirir evlendirmez diğer üçünden de kurtulmak için anında yeni görücüler çağırır. Bu sırada okullar açılır, kızların okula gitmesine izin verilmez. Babaanne ve dayının aklında onları evlendirme düşüncesi vardır, çünkü kızların eğitim alması, onların namussuz olarak yetişmesine sebep olabilir.

O yüzden evlendirilmeleri hem aile için hem de kızlar için daha iyi bir seçenektir. Leyla okula gidemediği için, eşyalarının kilitli olduğu dolabın anahtarını bulur. Ders kitaplarını alıp inceler. İncelediği ünite ise; "Hak ve Özgürlüklerimiz" konuludur. Burada, kızların içinde bulunduğu durum ile ünitedeki konu arasında bir tezatlık kurulmaktadır.

Sıra, Ece için görücülerin gelmesine gelir. Ece ise artık yorulmuştur. Tepki bile vermez. Boyun eğmiş gibidir. Ece, sözlendirildiği günden sonra iyice sessizleşir. Konuşmaz. Yaptı̆̆ tek eylem ise yemek yemektir. Leyla ise, evdeki artan baskıdan iyice bunalmıştır. İstanbul'a gitmek ister. Evden kaçıp yürümeye başlar. Dağlar ve uçurumlarla dolu kıyı şeridi boyunca yürür.

Daha önce, maça gitmeden tanıştığı Yasin ile karşılaşır. Yasin onu durdurur. Eve geri döner. Gece olduğunda; karanlık koridorda kızların amcası görülür. Bir odaya girer. Odadan kemer sesi gelir. Ardından da kesik bir ses gelir. Kızların amcaları, kameranın göstermediği biriyle ilişkiye girmektedir. Burada, aile içi cinsel taciz meselesi de eleştirilmiştir. 
Leyla, evden kaçmayı iyice düşünmeye başlar. Evden gizlice kaçıp Yasin'den araba sürüş dersleri almaya başlar. Bir gün eve gizli gizli girmeye çalışırken yakalanır. Bunun ardından; eve demirler gelir, kaynak yapılır. Ev iyice hapishane görünümü alır.

Filmde; ideal kadın nasıl olunur, kabul görülebilir kadın cinsiyet rolleri nedir, bunların hepsini bir sahnede geçen televizyon sahnesiyle görebiliriz. Kızlar yemek yemektedir. Televizyonda da bir din adamı, iffetli kadını anlatmaktadır: "Kadın iffetli olacak. Herkesin içinde kahkaha atmayacak. Bütün hareketlerinde cazibedar olmayacak...” Bu sözler sırasında da kızlar kendi aralarında eğlenmeye çalışırlar. Ece, sanki televizyonda duyduklarıyla dalga geçmek istermiş gibi, orta parmağını gösterir.

Kızlar kahkaha atmaya başlar. Kahkaha attıklarında babaanneleri ve amcaları rahatsız olur. Amcası; kızların kahkaha atmasına sebep olduğu için Ece'yi sofradan kovar. Ece'nin; "herkesin içinde kahkaha atması" ataerkil bir toplum için kabul edilemez. Kahkaha eden kadın da rolüne uygun davranmadığ için cezalandırılmalıdır. Fakat dayısının verdiği bu ceza Ece’ye fazla gelir. Gülerek odadan ayrılır ve dayısının silahını alarak intihar eder.

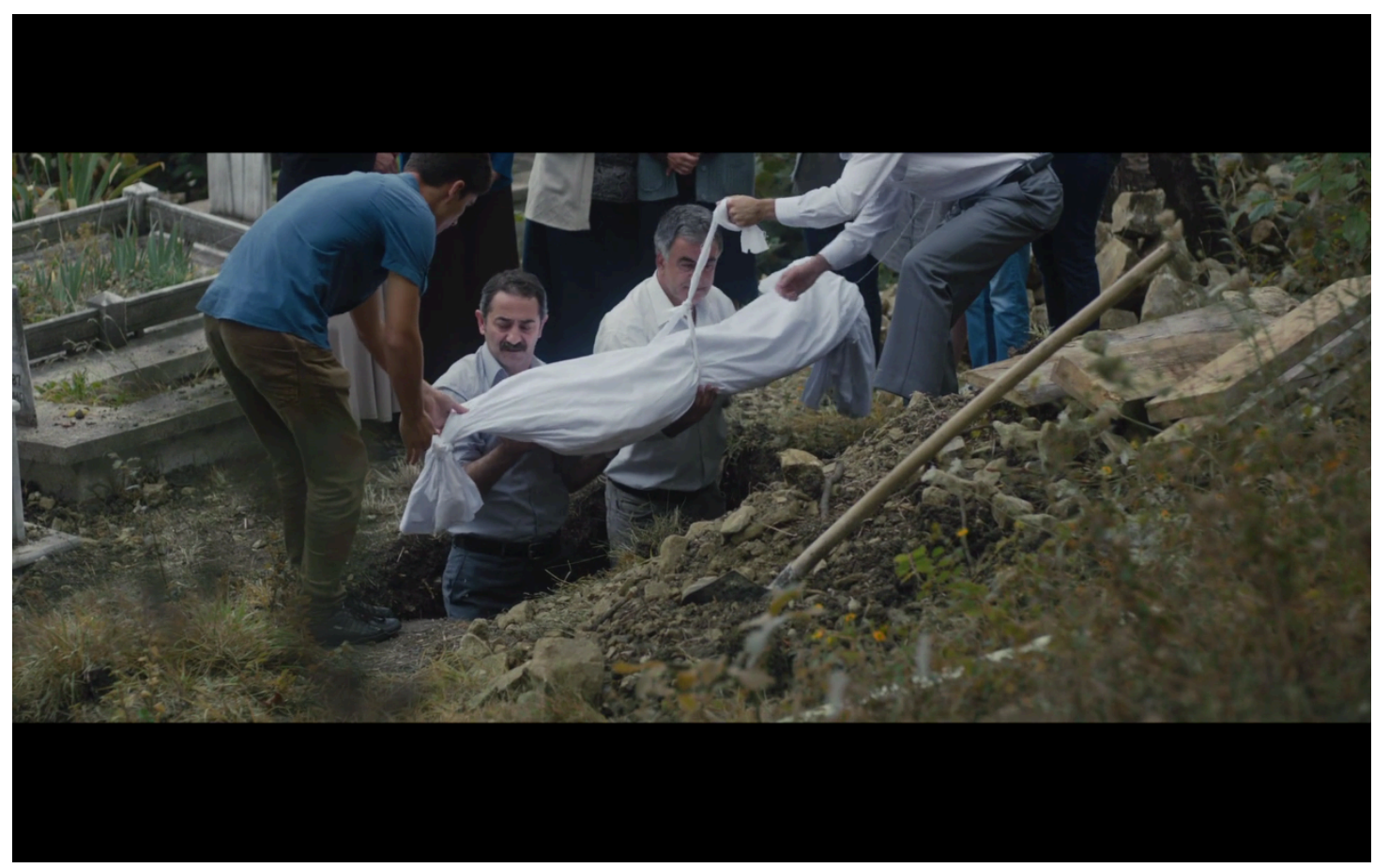

Sahne 5. Cenaze

Filmin sonlarına doğru geride kalan 2 kız kardeş evden kaçma planları yapar. At yelesine benzeyen saçlarını keserler. Yastıklara dikerler ve gittiklerini olabildiğince gizlemeye çalışacaklarından emin olurlar.

Babaanne ise; daha ergenliğini bile görmemiş torunu Nur'u evlendirmek ister. Bunca zamanlık birikimden, yasaklardan, hapis hayatından sonra; Lale isyan eder. Düğün gecesi geldiğinde, kapıları pencereleri kapatarak kız kardeşinin düğününü engellemeye çalışır. Nur da Leyla'ya katılır ve evde isyan çıkar. Amcaları, hapishaneye çevirdiği kendi evine, demir parmaklıklar yüzünden giremez.

Gençliklerinin ve tüm o baskının verdiği patlamayla; Mustang gibi, yani yabani bir at gibi saçlarını sallarlar. Babaannelerinin sakladığı parayı alıp, yanlarına da yiyecek alarak, uzun bir kovalamacanın ardından arabaya atlarlar. Arabayı; bir ağaca çarparak, kaza yapmış süsü verirler. Saklanırlar. Ardından Yasin gelir. Kızları otogara bırakır. Kızlar da otobüse binip İstanbul’a gider. 


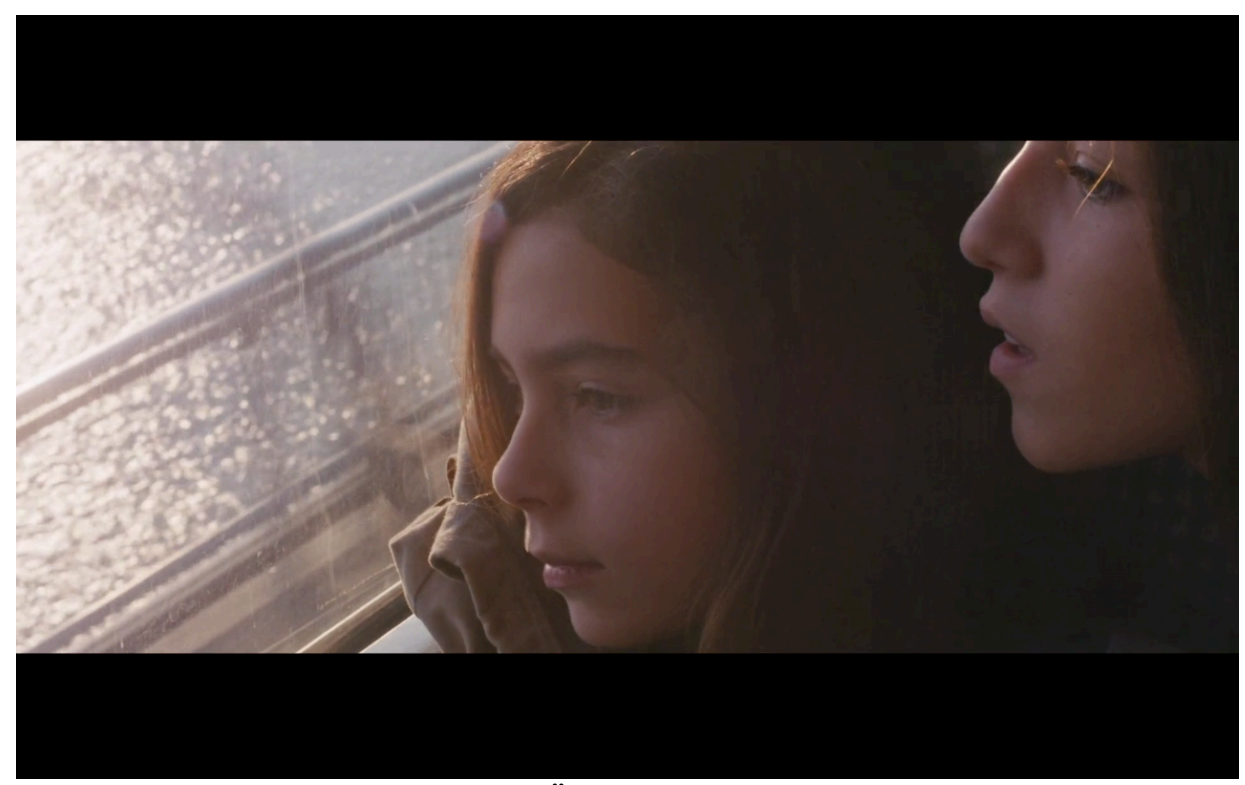

Sahne 6. Özgürlüğe Yolculuk

Filmdeki şu sahne, filmin adıyla tam bir uyum göstermektedir. Kızlar, Yasin'in üstü açık kamyonunun üstünde gitmektedir. Yasin arabayı gün batımına doğru sürer. Kızların, at yelesini anımsatan saçları rüzgarda uçuşmaktadır. Tıpkı, ağıldaki tutsaklığı sona eren yabani bir atın; ovalarda özgürce güneşe doğru koşarken, yelelerinin uçuşması gibi. Kızlar da İstanbul'a gider. İstanbul'da ise güneş doğmaktadır. Kızların artık özgür olup olmadığı ise seyircinin takdirine bırakılmıştır.

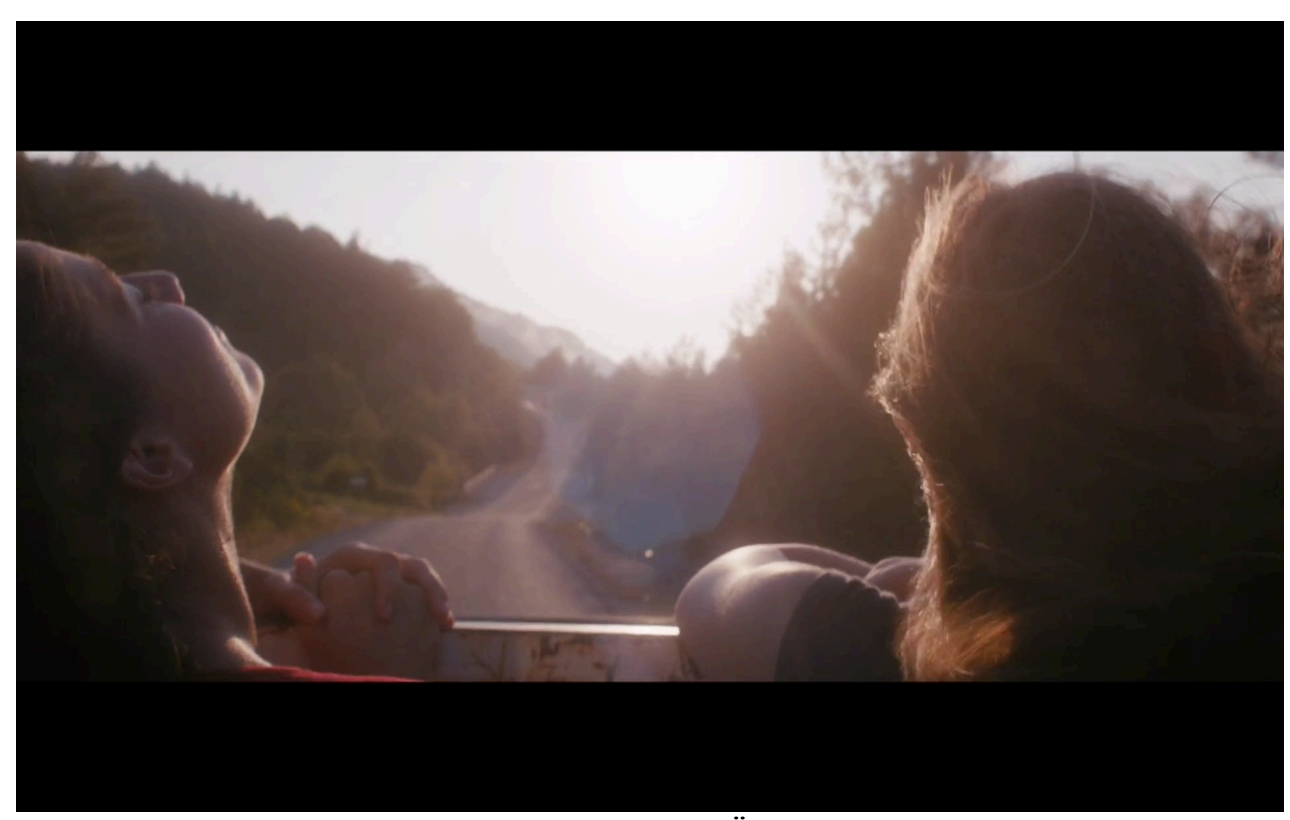

Sahne 7. Güneşin Doğuşunda Özgürlük Görüntüsü 


\section{BULGULAR, SONUÇ VE ÖNERILER}

Bu makalenin konusu olan "Mustang" filmi ve makaledeki toplumsal cinsiyet rollerini anlamaya yardımcı olacak filmler incelendiğinde; toplumsal cinsiyet rollerinin sinemaya yansıdığı, sinema tarafından da tekrar ve tekrar üretildiği sonucuna varılmaktadır.

Bu rollerin anlaşılması için; 2015 yılında yapılmış "Mustang" filmi çözümlenmiş; literatür taraması kısmında da, örnek gösterilebileceği düşünülmüş Türk sinemasındaki bazı filmler incelenmiştir. Bu inceleme sonucunda; aradan yaklaşık 50 yıl geçmesine rağmen; filmlerde toplumsal cinsiyet rollerine rastlanmaktadır. Fakat daha önce de belirtildiği gibi; bu roller, toplumdaki değişikliklerle birlikte değişmektedir. Yeşilçam dönemindeki kadının rolleriyle, "Mustang" filmindeki kadınların rolleri aynı olmamakla beraber; çoğu noktada benzeştikleri görülmektedir.

Toplumsal cinsiyet rollerinin; sinemaya da yansıması ise beklenen bir durumdur. Toplumsal cinsiyet rollerini; nasıl ki bir kültüre ait insanlar üretiyorsa; sinema da insan ürünüdür. İnsanların kültürüyle beslenen bir sanat dalidır.

"Mustang" filminde; $5 \mathrm{k}$ zz kardeşin, toplumsal cinsiyet rolleriyle yaşamlarının değişmesi anlatılmaktadır. Bu filmde karakterler; her ne kadar ataerkil düzenin oluşturduğu, toplumsal cinsiyet rollerine karşı bir direnme halinde olsalar da; film, yine de ataerkil toplumun söylemlerinden siyrilamamaktadır.

Ancak; Türkiye'de var olan belli başlı sorunlara (namus - kadın ilişkisi; toplumsal cinsiyet - kadından beklentiler, çocuk gelinler) açık ve cesur bir şekilde parmak bastığı ve mizahi unsurları da kullanarak eleştirdiği için; Türk sinemasındaki diğer filmlerden ayrılmaktadır. $\mathrm{Bu}$ film; özellikle doğu bölgelerindeki bireylerin, kadınlara karşı olan bakışını, yönetmenin bakış açısıyla da harmanlanmış şekliyle seyirciye aktarmaktadır.

Filmdeki karakterler; Türk sinemasındaki diğer karakterlere göre daha güçlü ve daha isyankardır. Ayrıca bu filmde karakterler; diğer Türk filmlerinde olduğu gibi ikincil ya da üçüncül planda yer almamakta, filmde geçen olayların merkezinde yer almaktadırlar. Ancak özgürlüğe kavuşmaları; yine bir erkek sayesinde olmaktadır.

Erkek karakterin (Yasin) yardımları olmasa; belki de karakterler, özgürlüklerine kavuşamayacaklardı. Buradan ise; erkeklerin yardımını alamamış kadınların yine başarısız olacağı, kadınların erkeklere muhtaç olduğu sonucuna varılabilir. Bu ise; filmdeki kadın - erkek ilişkileri arasındaki eşitsizliği yeniden üretmektedir. Ancak buna rağmen, film; bu konuyu işlemiş diğer filmlerden ayrılmaktadır.

“Mustang” filmi ile Türk sinemasında önemli adımlar atılmıştır. Toplumsal cinsiyet rolleri, doğudaki kadınların yaşamları ve çocuk gelinler gibi, Türkiye'nin bazı kesimlerinde hala daha tabu olan meselelerin gösterilmesi, filmin önemini arttırmaktadır. Filmin yönetmeninin kadın olması da, ataerkil düşünme şeklinden, biraz da olsa sıyrılıp, olaylara daha eleştirel bakılmasına olanak sağlamıştır.

Türk sinemasında yapılacak bu tarz filmler ile; kadın ile erkek arasındaki eşitsiz durum ve bu eşitsizliğin sürdürülmesini sağlayan toplumsal cinsiyet rolleri daha açık ve gözlemlenebilir hale gelebilir. Bu tarz filmlerin yapımının artmasıyla da sinema; toplumsal cinsiyet rollerinin, biraz da olsun değişmesine katkıda bulunabilir. 


\section{KAYNAKLAR}

Althusser, L. (2015), İdeoloji ve Devletin İdeolojik Aygıtlarl. Alp Tümertekin (Çev.), İstanbul: İthaki Yayinlart.

Aschcraft, A. M. ve Belgrave, F. Z. (2005) Gender Identity Development in Urban African American Girls. Ed: Janice W. Lee. Gender Roles. 1-31. New York: Nova.

Ataman, Ö.E. (2002). Sinemada Toplumsal Cinsiyet Rolleri: 1980-1999 Yıllarl Arasinda Türk Sineması'nda Toplumsal Cinsiyet Rollerinin Sunumu. Doktora Tezi. Eskişehir: Anadolu Üniversitesi, Sosyal Bilimler Enstitüsü.

Blank, H. (2008), Bekaretin El Değmemiş Tarihi. Emek Ergün (Çev.) İstanbul: İletişim Yayınları. Bordwell, D., Thompson K. (2012). Film Sanatı. Emrah Suat Onat, Ertan Yllmaz (Çev.) Ankara: De Ki Yayinevi.

Burr, V. (1998). Gender and Social Psychology. London: Routledge.

Carroll, J. L . (2010) Sexuality Now. Embracing Diversity. California: Wadsworth Cengage Learning. Connell, R.W. (2016). Toplumsal Cinsiyet ve İktidar. Cem Soydemir (Çev.) İstanbul: Ayrıntı Yayınları.

Erdal, Ç. (2010). Türkiye'de Ulusal Kanallarda Yaylnlanan Prime-Time Televizyon Dizilerinde Toplumsal Cinsiyet Rolleri Açısından Ailenin Sunumu. Yüksek Lisans Tezi. Eskişehir: Anadolu Üniversitesi, Sosyal Bilimler Enstitüsü.

Gordon, M. (2003). Sosyoloji Sözlüğü. Çev: Osman Akınhay, Derya Kömürcü. (Çev) Ankara: Bilim Sanat Yayinlart.

Güzel, M. Ş. (2006) Kadın Sineması. Istanbul: Peri Yayıları.

Haralambos, M. (1984) Sociology Themes and Perspectives. Bungay, Suffolk: University Tutorial Press

Illich, I. (1996). Gender. Ahmet Fethi. (Çev.) Ankara: Ayraç Yayınevi

Kandiyoti, D. (2015), Cariyeler, Bacılar, Yurttaşlar. Şirin Tekeli, Hüseyin Tapınç, Fevziye Sayılan, Aksu Bora, Ferhunde Özbay (Çev.) İstanbul: Metis Yayınları.

Lloyd, G. (2015). Erkek Akıl. Muttalip Özcan (Çev.) İstanbul: Ayrıntı Yayınları.

Lorber, J. (1994). Paradoxes of Gender. New Haven: Yale University Press.

Meaning of "mustang" in English Dictionary (ty.). Erişim Adresi: http://dictionary.cambridge.org/dictionary/english/mustang

Monaco, J. (2013). Bir Film Nasıl Okunur. Ertan Yılmaz (Çev.) İstanbul: Oğlak Yayıncılık.

Mustang (ty.). Erişim Adresi: http://www.beyazperde.com/filmler/film-228825/

Mustang (ty.). Erişim Adresi: http://www.imdb.com/title/tt3966404/awards?ref_=tt_awd

Onur, N. (2012) Kitle Kültürü Sineması ve B Filmi. Istanbul: Hayalperest Yayınevi.

Scognamillo, G. (2010) Türk Sinema Tarhi. İstanbul: Kabalcı Yayınlart.

Sigelman, C. K. ve Rider, E. A. (2009) Life-Span Human Development. Australia: Wadsworth Cengage Learning.

Suğur, S. (2006). Toplumsal Cinsiyet. Gürsel Yaktıl Ŏğuz (Ed.) Eskişehir: Anadolu Üniversitesi Açıköğretim Yayınları.

Tanner, D. (2013). Beni Hiç Anlamıyorsun. Osman Çetin Deniztekin (Çev.) İstanbul: Varlık Yayınları. Uğurlu, E.G. (2003) Türkiye'de Ulusal Televizyon Kanallarında Yaylnlanan Reklamlarda Annelik Rolünün Sunumu. Yüksek Lisans Tezi. Eskişehir: Anadolu Üniversitesi, Sosyal Bilimler Enstitüsü.

Vassaf, G. (2016). Cehenneme Övgü. Gündelik Hayatta Totalirizm, (31. Baskl). Zehra Gencosman, Ömer Madra (Çev.) İstanbul: İletişim Yayınları.

Wharton, A.S. (2005). The Sociology of Gender. Madlen, Massachusetts: Blackwell Publishing. Ögülmüss, S. (1991) İ̧̧erik Çözümlemesi. Ankara Üniversitesi Eğitim Bilimleri Fakültesi Dergisi. Cilt:24, Sayl: 1 (Elektronik Dergi) Erişim Adresi: http://dergiler.ankara.edu.tr/dergiler/40/506/6144.pdf 